\title{
tert-Butylsilylcyclopentadienyl Group 4 metal complexes
}

\author{
Regine Wolfgramm ${ }^{\mathrm{a}}$, Cristina Ramos ${ }^{\mathrm{a}}$, Pascual Royo ${ }^{\mathrm{a}, *}$, Maurizio Lanfranchi ${ }^{\mathrm{b}}$, \\ Maria Angela Pellinghelli ${ }^{\mathrm{b}}$, Antonio Tiripicchio ${ }^{\mathrm{b}}$ \\ a Departamento de Química Inorgánica, Universidad de Alcalá, Campus Universitario, 28871 Alcalá de Henares, Spain \\ ${ }^{\mathrm{b}}$ Dipartimento di Chimica Generale ed Inorganica, Chimica Analitica, Chimica Fisica, Università di Parma, Parco Area delle Scienze 17A, \\ I-43100 Parma, Italy
}

Received 3 May 2002; accepted 12 July 2002

Dedicated to Professor R. Usón with best affection and admiration

\begin{abstract}
New Group 4 metal $t$-butyldimethylsilylcyclopentadienyl complexes [ $\left.\mathrm{MCpCp}^{\prime} \mathrm{Cl}_{2}\right]\left(\mathrm{Cp}=\eta^{5}-\mathrm{C}_{5} \mathrm{H}_{5} ; \mathrm{Cp}^{\prime}=\eta^{5}-\mathrm{C}_{5} \mathrm{H}_{4} \mathrm{SiMe}_{2}^{t} \mathrm{Bu} ; \mathrm{M}=\right.$ $\operatorname{Ti} 4, \mathrm{Zr} 5$, Hf 6) were prepared by reaction of 1 equiv. of the lithium (2) and thallium (3) salts of $t$-butyldimethylsilylcyclopentadiene 1 with the monocyclopentadienyl complexes $\left[\mathrm{MCpCl}_{3} \cdot \mathrm{DME}\right](\mathrm{M}=\mathrm{Zr}, \mathrm{Hf})$ and $\left[\mathrm{TiCpCl}_{3}\right]$, respectively. A similar reaction using $\mathrm{ZrCl}_{4}(\mathrm{THF})_{2}$ and $\mathrm{HfCl}_{4}$ with 2 equiv. of the lithium salt 2 gave the symmetric $\left[\mathrm{MCp}_{2}^{\prime} \mathrm{Cl}_{2}\right](\mathrm{M}=\mathrm{Zr} 7, \mathrm{Hf} \mathbf{8})$ metallocenes. Alkylation of these compounds with 2 equiv. of $\mathrm{MgRCl}\left(\mathrm{R}=\mathrm{Me}, \mathrm{CH}_{2} \mathrm{Ph}\right)$ and $\mathrm{Li}\left(\mathrm{CH}_{2} \mathrm{CMe}_{2} \mathrm{Ph}\right)$ afforded the dialkyl complexes $\left[\mathrm{MCpCp} \mathrm{R}_{2}\right]$ $\left(\mathrm{R}=\mathrm{Me}, \mathrm{M}=\mathrm{Zr}\right.$ 9, $\mathrm{Hf} 10 ; \mathrm{R}=\mathrm{CH}_{2} \mathrm{Ph}, \mathrm{M}=\mathrm{Ti} 11, \mathrm{Zr} 12, \mathrm{Hf}$ 13), $\left[\mathrm{ZrCp}_{2}^{\prime}\left(\mathrm{CH}_{2} \mathrm{Ph}\right)_{2}\right] 14$ and $\left[\mathrm{ZrCpCp}^{\prime}\left(\mathrm{CH}_{2} \mathrm{CMe}_{2} \mathrm{Ph}\right)_{2}\right]$ 17. A Similar reaction of 5 with 1 equiv. of $\mathrm{Mg}\left(\mathrm{CH}_{2} \mathrm{Ph}\right) \mathrm{Cl}$ gave the monobenzyl compound $\left[\mathrm{ZrCpCp} \mathrm{Cl}^{\prime}\left(\mathrm{CH}_{2} \mathrm{Ph}\right)\right](\mathbf{1 5})$. Hydrolysis of 15 with a stoichiometric amount of water afforded the dinuclear $\mu$-oxo compound $\left[\left(\mathrm{ZrCpCp}^{\prime} \mathrm{Cl}\right)_{2}(\mu-\mathrm{O})\right](\mathbf{1 6})$. All of the new complexes reported were characterized by elemental analysis and ${ }^{1} \mathrm{H}$ and ${ }^{13} \mathrm{C}$ NMR spectroscopy and the molecular structures of 4 and 16 were determined by X-ray diffraction methods. Ethylene polymerization activities were measured for compounds 4-7.
\end{abstract}

(C) 2002 Elsevier Science B.V. All rights reserved.

Keywords: Titanium; Zirconium; Hafnium; ${ }^{t}$ Butylsilylcyclopentadienyl metallocenes; Ethylene polymerization

\section{Introduction}

Early transition metal cyclopentadienyl-type compounds have received special and intense research interest through their applications as Ziegler-Natta catalysts, and many articles reviewing these aspects have been published [1]. The introduction of different substituents in the cyclopentadienyl ring gives rise to significant changes in the reactivity and catalytic activity of these species [2], essentially derived from their different electronic and steric effects. Silyl substituents have been extensively used [3] with the main aim of introducing functionalized pendant moieties. We have reported many of these silyl substituted compounds which have been used more recently to stabilize cationic \footnotetext{
683.

* Corresponding author. Tel.: +34-91-8854-765; fax: +34-91-8854-

E-mail address: pascual.royo@uah.es (P. Royo).
}

zirconocene species [4] by coordinating the olefinic system of a silyl-allyl substituent and to isolate new 'doubly constrained' silyl- $\eta^{1}$-amido complexes [5]. Formation of cationic zirconocene complexes containing benzyl and the very bulky $\mathrm{Si}\left(\mathrm{SiMe}_{3}\right)_{3}$ substituted cyclopentadienyl ligands has been studied and the role of these substituents in ethylene polymerization has been considered [6]. Bulky substituents like tert-butyl groups are responsible for unexpected intramolecular activation processes such as those observed for benzyl and neophyl metallocenes [7] to give metallacyclic derivatives. Similar more open cycles are easily accessible as reported for molybdenum and tungsten derivatives [8].

tert-Butylsilyl is an appropriate group to introduce the required bulkiness producing slight modifications of the electronic properties afforded by a silyl substituent. For all these reasons we decided to study the synthesis of metallocenes containing tert-butylsilylcyclopentadienyl ligands. Here we report the synthesis of Group 4 
metallocenes containing this ligand, the $\mathrm{X}$-ray crystal structures of the dichloro $\left[\mathrm{Ti}\left(\eta^{5}-\mathrm{C}_{5} \mathrm{H}_{5}\right)\left(\eta^{5}-\mathrm{C}_{5} \mathrm{H}_{4} \mathrm{Si}\right.\right.$ $\left.\left.\mathrm{Me}_{2}^{t} \mathrm{Bu}\right) \mathrm{Cl}_{2}\right]$ and the $\mu$-oxo dinuclear $\left[\left\{\mathrm{Zr}\left(\eta^{5}-\right.\right.\right.$ $\left.\left.\left.\mathrm{C}_{5} \mathrm{H}_{4} \mathrm{SiMe}_{2}^{t} \mathrm{Bu}\right)\left(\eta^{5}-\mathrm{C}_{5} \mathrm{H}_{5}\right) \mathrm{Cl}_{2}\right\}(\mu-\mathrm{O})\right]$ complexes and the catalyitic activity of the chloro derivatives 4-7 for polymerization of ethylene.

\section{Results and discussion}

tert-Butyldimethylsilyl chloride is a usual commercial reagent extensively used as a protective group in organic synthesis [9]. Its reaction with sodium cyclopentadienide in 1/1 hexane/THF afforded the tert-butylsilylcyclopentadiene $\left[\mathrm{C}_{5} \mathrm{H}_{5} \mathrm{SiMe}_{2}^{t} \mathrm{Bu}\right]$ (1) which was isolated as a brown oily solid. Compound $\mathbf{1}$ was identified by ${ }^{1} \mathrm{H}$ NMR spectroscopy as a mixture of isomers in which the $\mathrm{sp}^{3}$ carbon-silyl bonded cyclopentadiene is the major component in a ratio of $70 \%$. The lithium salt $\mathrm{Li}\left(\mathrm{C}_{5} \mathrm{H}_{4^{-}}\right.$ $\mathrm{SiMe}_{2}^{t} \mathrm{Bu}$ ) (2) was the most appropriate reagent to transfer the ring to zirconium and hafnium while the thallium salt $\mathrm{Tl}\left(\mathrm{C}_{5} \mathrm{H}_{4} \mathrm{SiMe}_{2}^{t} \mathrm{Bu}\right)$ (3) was a better ring transfer reagent for titanium compounds to prevent further reoxidation processes that would otherwise result in reduced products. Metallation of 1 with $\mathrm{Li}-$ $n$-Bu and TlOEt afforded the lithium (2) and thallium (3) salts, respectively, which were used for subsequent transfer of the tert-butylsilylcyclopentadienyl ligand to different Group 4 metal chlorides.

As shown in Scheme 1, reaction of the thallium salt 3 with $\mathrm{CpTiCl}_{3}$ in toluene afforded the mixed dicyclopentadienyl titanium complex $\left[\mathrm{Ti}\left(\eta^{5}-\mathrm{C}_{5} \mathrm{H}_{5}\right)\left(\eta^{5}-\mathrm{C}_{5} \mathrm{H}_{4} \mathrm{Si}-\right.\right.$ $\left.\mathrm{Me}_{2}^{t} \mathrm{Bu}\right) \mathrm{Cl}_{2}$ ] (4), which after recrystallization in toluene

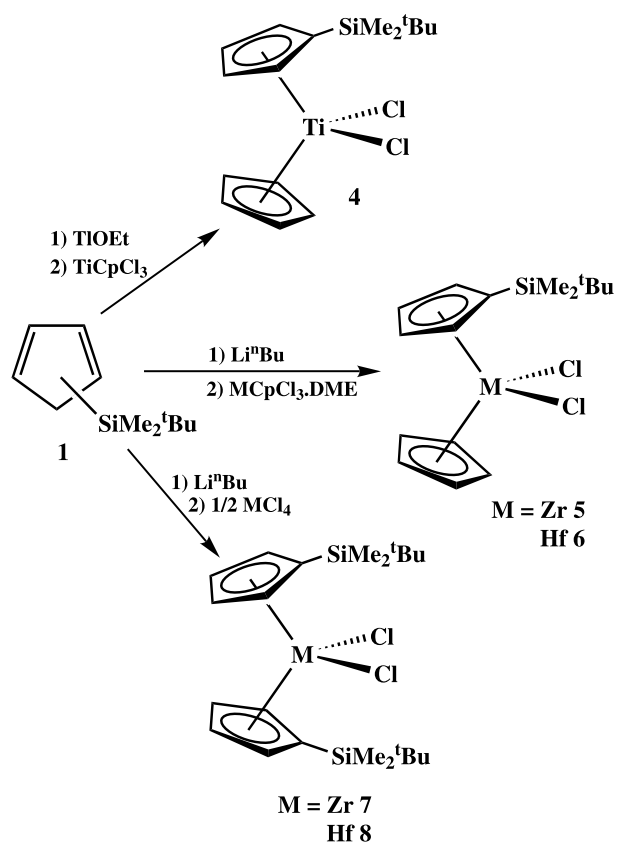

Scheme 1. was isolated as a red solid and characterized by elemental analysis, NMR spectroscopy and X-ray diffraction methods. Similar reactions using 1 equiv. of the lithiated cyclopentadienyl ligand with the zirconium and hafnium monocyclopentadienyl complexes $\left[\mathrm{CpMCl}_{3} \cdot \mathrm{DME}\right]$ in THF gave the mixed dicyclopentadienyl dichloro complexes $\left[\mathrm{M}\left(\eta^{5}-\mathrm{C}_{5} \mathrm{H}_{5}\right)\left(\eta^{5}-\mathrm{C}_{5} \mathrm{H}_{4} \mathrm{Si}\right.\right.$ $\left.\left.\mathrm{Me}_{2}^{t} \mathrm{Bu}\right) \mathrm{Cl}_{2}\right](\mathrm{M}=\mathrm{Zr}$ 5, Hf 6), isolated as beige and grey solids respectively and characterized by elemental analysis and NMR spectroscopy (see Section 4). The symmetric di(tert-butyldimethylsilylcyclopentadienyl) zirconium complex $\left[\mathrm{Zr}\left(\eta^{5}-\mathrm{C}_{5} \mathrm{H}_{4} \mathrm{SiMe}_{2}^{t} \mathrm{Bu}\right)_{2} \mathrm{Cl}_{2}\right]$ (7) was isolated as a beige solid from the reaction of 2 equiv. of the lithiated cyclopentadienyl ligand $\mathbf{2}$ with $\mathrm{ZrCl}_{4}(\mathrm{THF})_{2}$ in THF. Similar reaction with $\mathrm{HfCl}_{4}$ in THF gave, after evaporation and extraction into toluene, the symmetric dicyclopentadienyl hafnium complex $\left[\mathrm{Hf}\left(\eta^{5}-\mathrm{C}_{5} \mathrm{H}_{4} \mathrm{SiMe}_{2}^{t} \mathrm{Bu}\right)_{2} \mathrm{Cl}_{2}\right](\mathbf{8})$ which was isolated as a grey solid. Both compounds are soluble in toluene and scarcely soluble in hexanes and were characterized by analyses and NMR spectroscopy.

As shown in Scheme 2, the mixed metallocene dichlorides 4-6 were straightforwardly transformed into the dialkyl derivatives by reaction with the corresponding alkylating agents. Pure samples of neither the mono nor the dimethyltitanium complexes could be obtained using different molar ratios of $\mathrm{MgMeCl}$, whereas the dimethyl complexes $\left[\mathrm{M}\left(\eta^{5}-\mathrm{C}_{5} \mathrm{H}_{5}\right)\left(\eta^{5}\right.\right.$ $\left.\mathrm{C}_{5} \mathrm{H}_{4} \mathrm{SiMe}_{2}^{t} \mathrm{Bu}\right) \mathrm{Me}_{2}$ ] $(\mathrm{M}=\mathrm{Zr}$ 9, Hf 10) were easily prepared by reaction of the dichloro complexes $\mathbf{5}$ and 6 with 2 equiv. of methylmagnesium chloride in THF and isolated as yellow solids by crystallization from their hexane solutions. They were identified by chemical analyses and NMR spectroscopy.

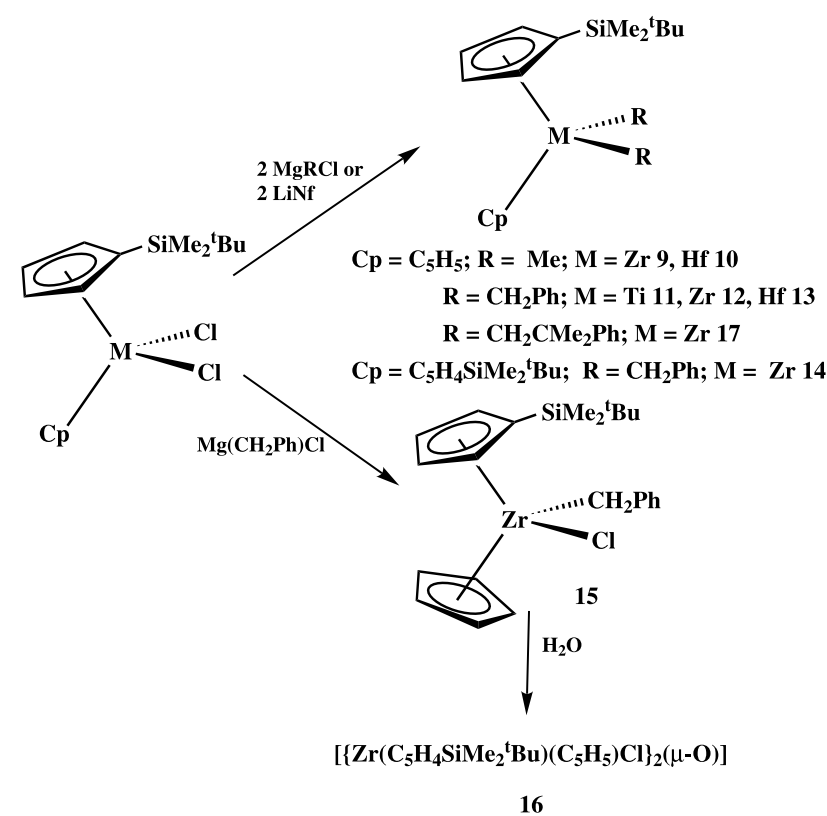

Scheme 2. 
Treatment of complexes 4-6 and 7 with 2 equiv. of $\mathrm{Mg}\left(\mathrm{CH}_{2} \mathrm{Ph}\right) \mathrm{Cl}$ in THF afforded the dibenzyl complexes $\left[\mathrm{M}\left(\eta^{5}-\mathrm{C}_{5} \mathrm{H}_{5}\right)\left(\eta^{5}-\mathrm{C}_{5} \mathrm{H}_{4} \mathrm{SiMe}_{2}^{t} \mathrm{Bu}\right)\left(\mathrm{CH}_{2} \mathrm{Ph}\right)_{2}\right](\mathrm{M}=\mathrm{Ti} \mathbf{1 1}$, $\mathrm{Zr} \mathrm{12}$, Hf 13) and $\left[\mathrm{Zr}\left(\eta^{5}-\mathrm{C}_{5} \mathrm{H}_{4} \mathrm{SiMe}_{2}^{t} \mathrm{Bu}\right)_{2}\left(\mathrm{CH}_{2} \mathrm{Ph}\right)_{2}\right]$ (14). Pure products were obtained as red (11), orange (12) and yellow (13) solids and a waxy oil (14) respectively and their formulation is consistent with the analytical and spectroscopic NMR data (see Section 4). An analogous reaction of the zirconocene dichloride (5) with 1 equiv. of $\mathrm{Mg}\left(\mathrm{CH}_{2} \mathrm{Ph}\right) \mathrm{Cl}$ in THF afforded the monobenzyl compound $\left[\mathrm{Zr}\left(\eta^{5}-\mathrm{C}_{5} \mathrm{H}_{5}\right)\left(\eta^{5}-\mathrm{C}_{5} \mathrm{H}_{4} \mathrm{Si}\right.\right.$ $\left.\left.\mathrm{Me}_{2}^{t} \mathrm{Bu}\right)\left(\mathrm{CH}_{2} \mathrm{Ph}\right) \mathrm{Cl}\right](\mathbf{1 5})$ as an orange solid, after crystallization from hexane at $-30{ }^{\circ} \mathrm{C}$.

All of the dimethyl $(\mathbf{9}, \mathbf{1 0})$ and dibenzyl (11-14) compounds and the monobenzylzirconium derivative $\mathbf{1 5}$ are soluble in toluene and hexanes and their solutions were moisture and oxygen sensitive, being easily hydrolyzed in the presence of traces of water. However, all could be stored as solids unaltered for long periods under an inert atmosphere. Controlled hydrolysis of complex 15 by addition of stoichiometric amounts of water to its toluene solution afforded the $\mu$-oxo dinuclear complex $\left[\mathrm{Zr}\left(\eta^{5}-\mathrm{C}_{5} \mathrm{H}_{5}\right)\left(\eta^{5}-\mathrm{C}_{5} \mathrm{H}_{4} \mathrm{SiMe}_{2}^{t} \mathrm{Bu}\right) \mathrm{Cl}\right]_{2}(\mu$ $\mathrm{O})$ ] (16), which was isolated as an orange crystalline solid and characterized by analysis, NMR spectroscopy and X-ray diffraction methods.

All of the alkyl compounds (9-15) were thermally stable when heated to $80{ }^{\circ} \mathrm{C}$, although the dibenzyl complexes (11-13) produced small amounts of dibenzyl after prolonged heating $(4 \mathrm{~h})$. There were no signs that the tert-butyl group became active under these conditions [7]. With the aim of checking the effect of a bulkier alkyl group we tried to isolate the neophyl derivatives. Pure samples of the titanium derivative could not be obtained although elimination of tert-butylbenzene was not observed. Treatment of the zirconium complex $\mathbf{5}$ with 2 equiv. of neophyl lithium in THF afforded the dialkyl zirconium complex $\left[\mathrm{Zr}\left(\eta^{5}-\mathrm{C}_{5} \mathrm{H}_{5}\right)\left(\eta^{5}-\mathrm{C}_{5} \mathrm{H}_{4} \mathrm{Si}\right.\right.$ $\left.\left.\mathrm{Me}_{2}^{t} \mathrm{Bu}\right)\left(\mathrm{CH}_{2} \mathrm{CMe}_{2} \mathrm{Ph}\right)_{2}\right]$ (17), which was isolated as a yellow solid after recrystallization from hexane at $-35{ }^{\circ} \mathrm{C}$ and characterized by analytical and spectroscopic NMR data (see Section 4). Compound 17 was also thermally stable when heated to $80{ }^{\circ} \mathrm{C}$ and prolonged heating caused decomposition without activating the tert-butyl substituent.

Following a well-known method we used ${ }^{1} \mathrm{H}$ NMR spectroscopy to monitor the generation of the cationic species by addition of 1 equiv. of $\mathrm{B}\left(\mathrm{C}_{6} \mathrm{~F}_{5}\right)_{3}$ to a $\mathrm{CD}_{2} \mathrm{Cl}_{2}$ solution of 12 in a sealed NMR tube at $-78{ }^{\circ} \mathrm{C}$. The NMR spectrum recorded in $\mathrm{CD}_{2} \mathrm{Cl}_{2}$ at $-80{ }^{\circ} \mathrm{C}$ showed the characteristic resonances of non-coordinated $\left[\left(\mathrm{CH}_{2} \mathrm{Ph}\right) \mathrm{B}\left(\mathrm{C}_{6} \mathrm{~F}_{5}\right)_{3}\right]^{-}\left(\begin{array}{ll}\delta & 2.74\end{array}\right)$ and demonstrated the formation of the cationic species $\left[\mathrm{Zr}\left(\eta^{5}-\mathrm{C}_{5} \mathrm{H}_{5}\right)\left(\eta^{5}\right.\right.$ $\left.\left.\mathrm{C}_{5} \mathrm{H}_{4} \mathrm{SiMe}_{2}^{t} \mathrm{Bu}\right)_{2}\left(\mathrm{CH}_{2} \mathrm{Ph}\right)\right]^{+}\left(\mathbf{1 2}^{+}\right)$(see Section 4). Reversible dynamic behaviour was observed for $\mathbf{1 2}^{+}$ between -80 and $0{ }^{\circ} \mathrm{C}$ with the coalescence temperature at $-60{ }^{\circ} \mathrm{C}$.

The base-free complex $\mathbf{1 2}^{+}$is stable at low temperature and decomposes at room temperature by reaction with the solvent $\mathrm{CD}_{2} \mathrm{Cl}_{2}$ to give the dichloro derivative. Compared with previously reported zirconium complexes [7] this cationic species $\mathbf{1 2}^{+}$does not activate the tert-butyl $\mathrm{C}-\mathrm{H}$ which would give a metallacyclic species.

\subsection{Structural studies}

All of the dichloro (4-8) and dialkyl (9-14, 17) symmetric and mixed metallocene complexes have $C_{2 v}$ and $C_{s}$ symmetry respectively with their ${ }^{1} \mathrm{H}$ NMR spectra showing the two multiplets typically expected for the $\mathrm{AA}^{\prime} \mathrm{BB}^{\prime}$ spin system of the tert-butylsilylsubstituted cyclopentadienyl ring, and one singlet for the unsubstituted cyclopentadienyl ring. One additional singlet is observed for both equivalent methyl groups of the dimethyl derivatives $\mathbf{9 , 1 0}$ whereas the diastereotopic hydrogens of the benzyl 11-13, and neophyl 17 complexes give rise to a characteristic doublet of doublets. In addition, the diastereotopic methyl groups of the neophyl 17 complex are observed as two singlets. However, only one singlet is observed for all four equivalent methylenic hydrogens of the $C_{2 v}$ symmetric dibenzyl complex 14. The $\mu$-oxo dinuclear zirconium complex 16 and the mono-benzyl mixed metallocene $\mathbf{1 5}$ are chiral molecules with ${ }^{1} \mathrm{H}$ NMR spectra showing the expected four multiplets for a ABCD spin system of the substituted cyclopentadienyl ring and the typical doublet of doublets for the diastereotopic methylenic hydrogens of the benzyl (15) groups.

Suitable crystals of complex $\mathbf{4}$ were obtained by very slow evaporation of its toluene solution at room temperature under nitrogen atmosphere. A view of the molecular structure is shown in Fig. 1 together with the

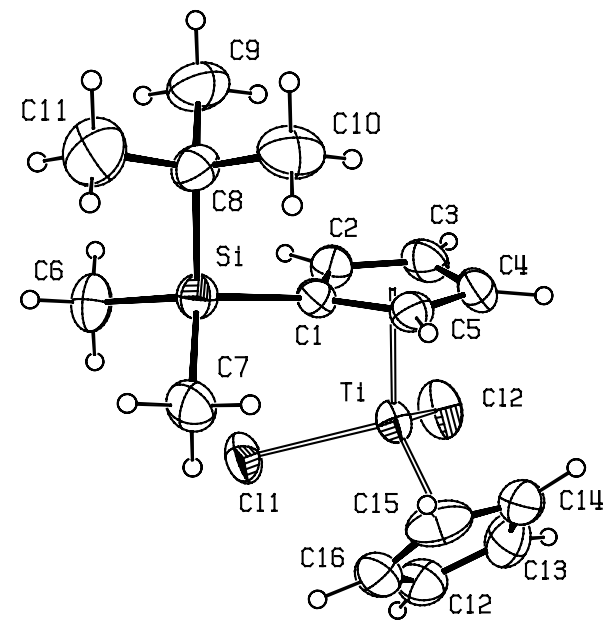

Fig. 1. Perspective view of the compound $\left[\mathrm{Ti}\left(\eta^{5}-\mathrm{C}_{5} \mathrm{H}_{4} \mathrm{SiMe}_{2}^{t} \mathrm{Bu}\right)\left(\eta^{5}-\right.\right.$ $\left.\left.\mathrm{C}_{5} \mathrm{H}_{5}\right) \mathrm{Cl}_{2}\right]$ (4). 
Table 1

Selected bond lengths $(\AA)$ and bond angles $\left({ }^{\circ}\right)$ for 4

\begin{tabular}{lcll}
\hline Bond lengths & & & \\
$\mathrm{Ti}-\mathrm{Cl}(1)$ & $2.344(1)$ & $\mathrm{Ti}-\mathrm{Cl}(2)$ & $2.385(1)$ \\
$\mathrm{Ti}-\mathrm{CE}(1)$ & $2.060(4)$ & $\mathrm{Ti}-\mathrm{CE}(2)$ & $2.050(5)$ \\
$\mathrm{Ti}-\mathrm{C}(1)$ & $2.418(4)$ & $\mathrm{Ti}-\mathrm{C}(12)$ & $2.348(5)$ \\
$\mathrm{Ti}-\mathrm{C}(2)$ & $2.390(4)$ & $\mathrm{Ti}-\mathrm{C}(13)$ & $2.359(5)$ \\
$\mathrm{Ti}-\mathrm{C}(3)$ & $2.378(4)$ & $\mathrm{Ti}-\mathrm{C}(14)$ & $2.357(5)$ \\
$\mathrm{Ti}-\mathrm{C}(4)$ & $2.333(4)$ & $\mathrm{Ti}-\mathrm{C}(15)$ & $2.357(5)$ \\
$\mathrm{Ti}-\mathrm{C}(5)$ & $2.373(4)$ & $\mathrm{Ti}-\mathrm{C}(16)$ & $2.366(5)$ \\
$\mathrm{Si}-\mathrm{C}(1)$ & $1.885(4)$ & $\mathrm{Si}-\mathrm{C}(7)$ & $1.858(4)$ \\
$\mathrm{Si}-\mathrm{C}(6)$ & $1.863(4)$ & $\mathrm{Si}-\mathrm{C}(8)$ & $1.889(4)$ \\
Bond angles & & & \\
$\mathrm{Cl}(1)-\mathrm{Ti}-\mathrm{CE}(1)$ & $107.6(1)$ & $\mathrm{Cl}(1)-\mathrm{Ti}-\mathrm{CE}(2)$ & $106.7(1)$ \\
$\mathrm{Cl}(2)-\mathrm{Ti}-\mathrm{CE}(1)$ & $106.4(1)$ & $\mathrm{Cl}(2)-\mathrm{Ti}-\mathrm{CE}(2)$ & $106.0(1)$ \\
$\mathrm{Cl}(1)-\mathrm{Ti}-\mathrm{Cl}(2)$ & $92.15(5)$ & $\mathrm{CE}(1)-\mathrm{Ti}-\mathrm{CE}(2)$ & $131.1(2)$ \\
\hline
\end{tabular}

$\mathrm{CE}(1)$ and $\mathrm{CE}(2)$ are the centroids of the $\mathrm{C}(1)-\mathrm{C}(5)$ and $\mathrm{C}(12)-$ $\mathrm{C}(16)$ cyclopentadienyl rings, respectively.

atomic numbering system. Selected bond distances and angles are given in Table 1.

The Ti atom is surrounded by two terminal chlorine atoms, a $\eta^{5}-\mathrm{Cp}$ and a $\eta^{5}-\mathrm{C}_{5} \mathrm{H}_{4} \mathrm{SiMe}_{2}^{t} \mathrm{Bu}$ ligand and the coordination can be described as tetrahedral if the two centroids of the $\mathrm{Cp}$ rings are considered as coordination sites. The $\mathrm{Ti}-\mathrm{Cl}(2)$ bond length is significantly longer than the $\mathrm{Ti}-\mathrm{Cl}(1)$ one. Nevertheless these values fall in the range [2.317-2.386 $\AA$ ] found in other mononuclear titanocene dichloro derivatives containing at least a $\mathrm{Cp}-$ $\mathrm{SiR}_{3}$ ligand, retrieved from a bibliographic search on the Cambridge Structural Database.

Single crystals of complex $\mathbf{1 6}$ appropriate for X-ray diffraction studies were obtained by cooling its hexane solution to $-35{ }^{\circ} \mathrm{C}$. A view of the molecular structure of $\mathbf{1 6}$ is shown in Fig. 2 together with the atomic numbering system. Selected bond distances and angles are given in Table 2 .

The dinuclear complex, with the oxygen atom bridging the two zirconium atoms presents a crystallographic
Table 2

Selected bond lengths $(\AA)$ and bond angles $\left(^{\circ}\right)$ for $\mathbf{1 6}$

\begin{tabular}{lcll}
\hline Bond lengths & & & \\
$\mathrm{Zr}-\mathrm{O}$ & $1.9520(6)$ & $\mathrm{Zr}-\mathrm{Cl}$ & $2.4723(11)$ \\
$\mathrm{Zr}-\mathrm{CE}(1)$ & $2.228(3)$ & $\mathrm{Zr}-\mathrm{CE}(2)$ & $2.233(4)$ \\
$\mathrm{Zr}-\mathrm{C}(1)$ & $2.559(3)$ & $\mathrm{Zr}-\mathrm{C}(12)$ & $2.511(3)$ \\
$\mathrm{Zr}-\mathrm{C}(2)$ & $2.536(3)$ & $\mathrm{Zr}-\mathrm{C}(13)$ & $2.507(3)$ \\
$\mathrm{Zr}-\mathrm{C}(3)$ & $2.533(3)$ & $\mathrm{Zr}-\mathrm{C}(14)$ & $2.544(3)$ \\
$\mathrm{Zr}-\mathrm{C}(4)$ & $2.489(3)$ & $\mathrm{Zr}-\mathrm{C}(15)$ & $2.542(3)$ \\
$\mathrm{Zr}-\mathrm{C}(5)$ & $2.539(3)$ & $\mathrm{Zr}-\mathrm{C}(16)$ & $2.546(3)$ \\
$\mathrm{Si}-\mathrm{C}(1)$ & $1.877(3)$ & $\mathrm{Si}-\mathrm{C}(7)$ & $1.871(5)$ \\
$\mathrm{Si}-\mathrm{C}(6)$ & $1.863(4)$ & $\mathrm{Si}-\mathrm{C}(8)$ & $1.903(4)$ \\
Bond angles & & & \\
$\mathrm{Cl}-\mathrm{Zr}-\mathrm{CE}(1)$ & $107.56(9)$ & $\mathrm{Cl}-\mathrm{Zr}-\mathrm{CE}(2)$ & $106.69(9)$ \\
$\mathrm{O}-\mathrm{Zr}-\mathrm{CE}(1)$ & $107.26(8)$ & $\mathrm{O}-\mathrm{Zr}-\mathrm{CE}(2)$ & $105.54(9)$ \\
$\mathrm{O}-\mathrm{Zr}-\mathrm{Cl}$ & $97.51(5)$ & $\mathrm{CE}(1)-\mathrm{Zr}-\mathrm{CE}(2)$ & $128.11(12)$ \\
$\mathrm{Zr}-\mathrm{O}-\mathrm{Zr} r^{\prime}$ & $172.24(15)$ & &
\end{tabular}

$\mathrm{CE}(1)$ and $\mathrm{CE}(2)$ are the centroids of the $\mathrm{C}(1)-\mathrm{C}(5)$ and $\mathrm{C}(12)-$ $\mathrm{C}(16)$ cyclopentadienyl rings, respectively.

C2 symmetry with the twofold axis passing through the oxygen atom. The tetrahedral coordination of the zirconium atoms (if the two centroids of the $\mathrm{Cp}$ rings are considered as coordination sites) is completed by a terminal chlorine atom, a $\eta^{5}-\mathrm{Cp}$ and a $\eta^{5}-\mathrm{C}_{5} \mathrm{H}_{4} \mathrm{SiMe}_{2}^{t} \mathrm{Bu}$ ligand. The metal is chiral and the complex depicted in Fig. 1 adopts a $R, R$ configuration, even if in the crystals both enantiomers $R, R$ and $S, S$ are present (the space group being centrosymmetric). The $\mathrm{Zr}-\mathrm{O}$ and the $\mathrm{Zr}$ $\mathrm{Cl}$ bond distances $[1.9520(6)$ and $2.4723(11) \AA$, respectively] are in the range [ $\mathrm{Zr}-\mathrm{O} 1.942-1.959 \AA]$ [10-13], $[\mathrm{Zr}-\mathrm{Cl} 2.436-2.480 \AA][11,12]$ found in other $\mu$-oxozirconocene derivatives. In the $\eta^{5}-\mathrm{C}_{5} \mathrm{H}_{4} \mathrm{SiMe}_{2}^{t} \mathrm{Bu}$ ligand the $\mathrm{Si}$ atom is out of the $\mathrm{Cp}$ ring of $0.325(1) \AA$ on the opposite site of the $\mathrm{Zr}$ atom and the bulky ${ }^{t} \mathrm{Bu}$ group is in an axial conformation with respect to the $\mathrm{Cp}$ ring $(\mathrm{C}(8)-\mathrm{Si}-\mathrm{C}(1)-\mathrm{C}(2))=\left(92.4(3)^{\circ}\right)$, similar values were found also for $4\left(0.321(1) \AA\right.$ and $\left.89.6(3)^{\circ}\right)$. The $\mathrm{Zr}-\mathrm{O}-$ $\mathrm{Zr}^{\prime}$ bridge is almost linear (the angle is $172.24(15)^{\circ}$ ), as

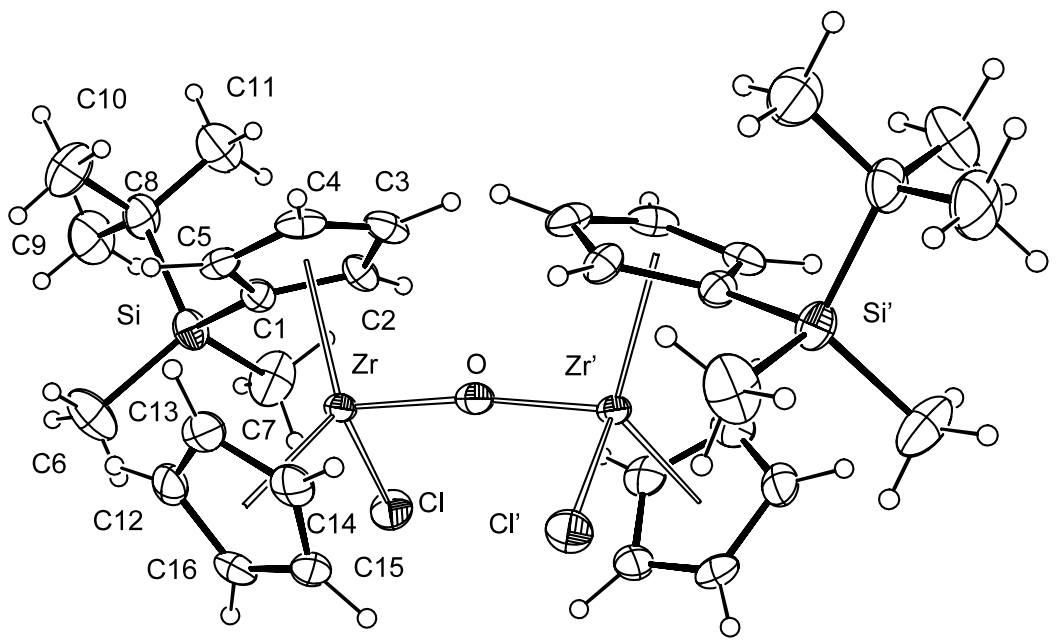

Fig. 2. Perspective view of the compound $\left.\left[\left\{\mathrm{Zr}\left(\eta^{5}-\mathrm{C}_{5} \mathrm{H}_{4} \mathrm{SiMe}_{2}^{t} \mathrm{Bu}\right)\left(\eta^{5}-\mathrm{C}_{5} \mathrm{H}_{5}\right) \mathrm{Cl}\right]_{2}\right\}(\mu-\mathrm{O})\right](\mathbf{1 6})$. 
found in the previously mentioned $\mu$-oxo-zirconocene derivatives (values in the range 159.6-180 ${ }^{\circ}$ ) [10-13].

\subsection{Ethylene polymerization studies}

The catalytic activity of the titanium (4), zirconium (5, 7) and hafnium (6) dichloro complexes in ethylene polymerization was investigated using methylalumoxane (MAO) as cocatalyst at $21{ }^{\circ} \mathrm{C}$ under $1 \mathrm{~atm}$. of ethylene. As expected, the hafnium complex $\mathbf{6}$ was not active whereas the symmetrical zirconium complex 7 with two more bulky tert-butylsilyl substituted rings showed an activity of $1.4 \times 10^{6} \mathrm{~g} \mathrm{PE}(\mathrm{mol} \text { cat. } \mathrm{h})^{-1}$, higher than that found for bulkier substituted rings [6] and similar to that observed for the titanium derivative $\mathbf{4}$ with only one substituted ring $\left(1.3 \times 10^{6} \mathrm{~g} \mathrm{PE}(\mathrm{mol} \mathrm{cat} . \mathrm{h})^{-1}\right)$. The activity of the related less crowded mixed zirconocene $\mathbf{5}$ was slightly higher $\left(1.9 \times 10^{6} \mathrm{~g}\right.$ PE (mol cat. h) $\left.{ }^{-1}\right)$ but lower than that reported for the related $\left[\mathrm{Zr}\left(\mathrm{C}_{5} \mathrm{H}_{4} \mathrm{Si}\right.\right.$ $\left.\mathrm{Me}_{3}\right) \mathrm{CpCl}_{2}$ ] complex used as a reference $\left(12.8 \times 10^{6} \mathrm{~g}\right.$ $\mathrm{PE}$ (mol cat. h) ${ }^{-1}$ ), indicating the steric influence of the bulky tert-butyl substituent.

\section{Conclusions}

New dichloro metallocene-type Group 4 metal complexes containing tert-butylsilyl-substituted cyclopentadienyl ligands have been successfully isolated and alkylated to give dimethyl, dibenzyl and neophyl compounds. All have been thoroughly characterized by chemical analysis and ${ }^{1} \mathrm{H}$ and ${ }^{13} \mathrm{C}$ NMR spectroscopy. No activation of the tert-butyl $\mathrm{C}-\mathrm{H}$ bonds was observed under any conditions and the alkyl complexes were thermally stable. The mixed metallocene dibenzyl zirconium complex reacts with the Lewis acid $\mathrm{B}\left(\mathrm{C}_{6} \mathrm{~F}_{5}\right)_{3}$ at $-80{ }^{\circ} \mathrm{C}$ to generate a mononuclear cationic species, which shows dynamic behaviour between -80 and $0{ }^{\circ} \mathrm{C}$ with the coalescence temperature at $-60{ }^{\circ} \mathrm{C}$. The dichloro metallocene complexes activated with MAO were used as catalysts for ethylene polymerization. The zirconium derivatives were the most active species although their activities are significantly lower than that observed for the less crowded $\left[\mathrm{Zr}\left(\mathrm{C}_{5} \mathrm{H}_{4} \mathrm{Si}-\right.\right.$ $\left.\mathrm{Me}_{3}\right) \mathrm{CpCl}_{2}$.

\section{Experimental}

All manipulations were performed either under argon using Schlenk techniques or in a glovebox. Solvents were purified by distillation from an appropriate deoxygenated drying agent (sodium for toluene and THF and sodium/potassium alloy for hexane). $n$-BuLi (1.6 M hexane), $\mathrm{BzMgCl}$ (2 M THF), $\mathrm{MeMgCl}$ (3 M diethylether), $\mathrm{ClSiMe}_{2}^{t} \mathrm{Bu}, \mathrm{TlOC}_{2} \mathrm{H}_{5}, \mathrm{HfCl}_{4}$ and $\mathrm{ZrCl}_{4}$ were obtained commercially and used without purification. $\mathrm{Zr}\left(\eta^{5}-\mathrm{C}_{5} \mathrm{H}_{5}\right) \mathrm{Cl}_{3}$. DME, $\mathrm{Hf}\left(\eta^{5}-\mathrm{C}_{5} \mathrm{H}_{5}\right) \mathrm{Cl}_{3} \cdot$ DME [14], $\mathrm{ZrCl}_{4}(\mathrm{THF})_{2}$ [15] and $\mathrm{B}\left(\mathrm{C}_{6} \mathrm{~F}_{5}\right)_{3}$ [16] were prepared by reported methods. $\mathrm{LiCH}_{2} \mathrm{CMe}_{2} \mathrm{Ph}$ was prepared as a yellow microcrystalline solid by reaction of lithium metal with $\mathrm{ClCH}_{2} \mathrm{CMe}_{2} \mathrm{Ph}$ (Aldrich) in hexane under reflux for one week. ${ }^{1} \mathrm{H}$ and ${ }^{13} \mathrm{C}$ NMR spectra were recorded on Varian Unity FT-300 and Varian Unity FT-500 Plus instruments, and chemical shifts were measured relative to residual ${ }^{1} \mathrm{H}$ and ${ }^{13} \mathrm{C}$ resonances of the deuterated solvents $\mathrm{C}_{6} \mathrm{D}_{6}(\delta=7.15 \mathrm{pm}), \mathrm{CDCl}_{3}(\delta=$ $7.24 \mathrm{pm})$ and $\mathrm{C}_{6} \mathrm{D}_{6}(\delta=128.0 \mathrm{pm}), \mathrm{CDCl}_{3}(\delta=77.0$ $\mathrm{pm})$, respectively. $\mathrm{C}, \mathrm{H}$ analyses were run on a PerkinElmer 240 microanalyzer.

\subsection{Synthesis of $\mathrm{C}_{5} \mathrm{H}_{5} \mathrm{SiMe}_{2}^{t} \mathrm{Bu}$ (1)}

A solution of $\mathrm{ClSiMe}_{2}^{t} \mathrm{Bu}(6.93 \mathrm{~g}, 46 \mathrm{mmol})$ in $\mathrm{THF}$ (30 ml) was added to a solution of $\mathrm{C}_{5} \mathrm{H}_{5} \mathrm{Na}(4.05 \mathrm{~g}, 46$ $\mathrm{mmol})$ in THF $(40 \mathrm{ml}) /$ hexane $(70 \mathrm{ml})$ and the mixture was stirred for 2 days at room temperature (r.t.). The solvents were removed in vacuo and the residue was extracted into hexane $(2 \times 50 \mathrm{ml})$. After evaporation of the solvent the residue was redisolved in hexane $(40 \mathrm{ml})$, filtered and dried under vacuum to give $\mathbf{1}$ as a brown oily solid (5,72 g, 31,7 mmol, 69\%). ${ }^{1} \mathrm{H}$ NMR: $\left(\mathrm{C}_{6} \mathrm{D}_{6}\right.$, $\left.25{ }^{\circ} \mathrm{C}, 300 \mathrm{MHz}\right): \delta 0.13$ (s, 6H, SiMe $), 0.91$ (s, 9H, $\left.\mathrm{CMe}_{3}\right), 3.54\left(\mathrm{~m}, 1 \mathrm{H}, \mathrm{Cp}-\mathrm{H}_{\text {allyl }}\right), 6.55,6.57(2 \mathrm{~m}, 4 \mathrm{H}$, $\mathrm{C}_{5} \mathrm{H}_{4}$ ).

\subsection{Synthesis of $\mathrm{Li}\left[\mathrm{C}_{5} \mathrm{H}_{4} \mathrm{SiMe}_{2}^{t} \mathrm{Bu}\right]$ (2)}

A solution of $1(5,10 \mathrm{~g}, 28.3 \mathrm{mmol})$ in hexane $(50 \mathrm{ml})$ was treated at $-78{ }^{\circ} \mathrm{C}$ with a $1.6 \mathrm{M}$ hexane solution of $\mathrm{Li}^{\mathrm{n}} \mathrm{Bu}(18.0 \mathrm{ml}, 28.8 \mathrm{mmol})$. The mixture was allowed to warm to r.t. and stirred for $3 \mathrm{~h}$ until gas evolution had completely ceased. The solvent was removed in vacuo and the resulting white solid was washed with hexane and dried under vacuum to be identified as $2(5,01 \mathrm{~g}$, $26.9 \mathrm{mmol}, 95 \%) .{ }^{1} \mathrm{H}$ NMR: $\left(\mathrm{C}_{5} \mathrm{D}_{5} \mathrm{~N}+\mathrm{C}_{6} \mathrm{D}_{6}, 25{ }^{\circ} \mathrm{C}\right.$, $300 \mathrm{MHz}$ ): $\delta 0.38$ (s, $\left.6 \mathrm{H}, \mathrm{Si} M e_{2}\right), 1.17$ (s, 9H, $C M e_{3}$ ), 6.61, 6.62(2m, $\left.4 \mathrm{H}, \mathrm{C}_{5} \mathrm{H}_{4}\right)$.

\subsection{Synthesis of $\mathrm{Tl}\left[\mathrm{C}_{5} \mathrm{H}_{4} \mathrm{SiMe}_{2}^{t} \mathrm{Bu}\right]$ (3)}

$\mathrm{TlOC}_{2} \mathrm{H}_{5}(4.24 \mathrm{~g}, 17.0 \mathrm{mmol})$ was added at $0{ }^{\circ} \mathrm{C}$ to a diethylether $(70 \mathrm{ml})$ solution of the cyclopentadiene $\mathbf{1}$ $(3.07 \mathrm{~g}, 17.0 \mathrm{~mol})$. The mixture was allowed to warm to r.t. and stirred for 1 day. After the solvent was evaporated, the resulting solid was washed with hexane and dried under vacuum to be characterized as the title compound (2.20 g, $12.2 \mathrm{mmol}, 72 \%)$. Anal. Calc. for $\mathrm{C}_{11} \mathrm{H}_{19} \mathrm{SiTl}: \mathrm{C}, 34.43 ; \mathrm{H}, 4.99$. Found: $\mathrm{C}, 33.83 ; \mathrm{H}$, $5.16 \%$. 
4.4. Synthesis of $\left[\mathrm{Ti}\left(\eta^{5}-\mathrm{C}_{5} \mathrm{H}_{4} \mathrm{SiMe}{ }_{2}^{t} \mathrm{Bu}\right)\left(\eta^{5}-\mathrm{C}_{5} \mathrm{H}_{5}\right) \mathrm{Cl}_{2}\right]$ (4)

Toluene $(50 \mathrm{ml})$ was added to a mixture of $\mathbf{3}(1.00 \mathrm{~g}$, $2.6 \mathrm{mmol})$ and $\left[\mathrm{Ti}\left(\eta^{5}-\mathrm{C}_{5} \mathrm{H}_{5}\right) \mathrm{Cl}_{3}\right](0.57 \mathrm{~g}, 2.6 \mathrm{mmol})$ at r.t. The mixture was heated under reflux for $4 \mathrm{~h}$ and then cooled to ambient temperature. After filtration to separate $\mathrm{TlCl}$, the red solution was concentrated and cooled to $-40{ }^{\circ} \mathrm{C}$ to give 4 as a red solid which was filtered, washed with hexane and dried under vacuum (0.58 g, $1.6 \mathrm{mmol}, 62 \%)$. Anal. Calc. for $\mathrm{C}_{16} \mathrm{H}_{24} \mathrm{SiTiCl}_{2}$ : C, 52.91; H, 6.66. Found: C, 52.41; H, 6.53\%. ${ }^{1} \mathrm{H}$ NMR $\left(\mathrm{CDCl}_{3}, 25{ }^{\circ} \mathrm{C}, 300 \mathrm{MHz}\right): \delta 0.31\left(\mathrm{~s}, 6 \mathrm{H}, \mathrm{Si} M e_{2}\right) ; 0.79$ (s, 9H, CMe 3 ); 6.54 (s, 5H, $\left.\mathrm{C}_{5} H_{5}\right) ; 6.62$ (t, 2H, $J=2.4$ $\left.\mathrm{Hz}, \mathrm{C}_{5} H_{4}\right) ; 6.83\left(\mathrm{t}, 2 \mathrm{H}, J=2.4 \mathrm{~Hz}, \mathrm{C}_{5} H_{4}\right) \cdot{ }^{13} \mathrm{C}\left\{{ }^{1} \mathrm{H}\right\}$ NMR $\left(\mathrm{CDCl}_{3}, 25{ }^{\circ} \mathrm{C}, 300 \mathrm{MHz}\right): \delta-5.7\left(\mathrm{SiMe}_{2}\right) ; 17.6$ $\left(\mathrm{CMe}_{3}\right) ; 26.5\left(\mathrm{CMe}_{3}\right) ; 120.2\left(C_{5} \mathrm{H}_{5}\right) ; 121.1\left(C_{5} \mathrm{H}_{4}\right) ; 121.6$ $\left(C_{5} \mathrm{H}_{4}\right.$ ipso $) ; 128.8\left(C_{5} \mathrm{H}_{4}\right)$.

\subsection{Synthesis of $\left[\mathrm{Zr}\left(\eta^{5}-\mathrm{C}_{5} \mathrm{H}_{4} \mathrm{SiMe}_{2}^{t} \mathrm{Bu}\right)\left(\eta^{5}-\mathrm{C}_{5} \mathrm{H}_{5}\right) \mathrm{Cl}_{2}\right]$} (5)

THF $(150 \mathrm{ml})$ was added at $-78{ }^{\circ} \mathrm{C}$ to a mixture of 2 $(1.14 \mathrm{~g}, 6.1 \mathrm{mmol})$ and $\left[\mathrm{Zr}\left(\mathrm{C}_{5} \mathrm{H}_{5}\right) \mathrm{Cl}_{3} \cdot \mathrm{DME}\right](2.15 \mathrm{~g}, 6.1$ $\mathrm{mmol}$ ). The mixture was allowed to warm slowly to r.t. and then stirred for an additional $6 \mathrm{~h}$. After the solvent was removed under vacuum, the residue was extracted into toluene $(50 \mathrm{ml})$. The solvent was evaporated to give $\mathbf{5}$ as a beige solid which was washed with hexane and dried under vacuum. (1.63 g, $4.0 \mathrm{mmol}, 65 \%)$. Anal. Calc. for $\mathrm{C}_{16} \mathrm{H}_{24} \mathrm{SiZrCl}_{2}$ : C, 47.27; H, 5.95. Found: $\mathrm{C}$, 47.72; H, 5.80\%. ${ }^{1} \mathrm{H}$ NMR $\left(\mathrm{C}_{6} \mathrm{D}_{6}, 25{ }^{\circ} \mathrm{C}, 300 \mathrm{MHz}\right): \delta$ 0.40 (s, 6H, SiMe $) ; 0.76$ (s, 9H, CMe 3 ); $5.92(\mathrm{t}, 2 \mathrm{H}, J=$ $\left.2.3 \mathrm{~Hz}, \mathrm{C}_{5} H_{4}\right) ; 5.94\left(\mathrm{~s}, 5 \mathrm{H}, \mathrm{C}_{5} H_{5}\right) ; 6.34(\mathrm{t}, 2 \mathrm{H}, J=2.3$ $\left.\mathrm{Hz}, \mathrm{C}_{5} \mathrm{H}_{4}\right) .{ }^{1} \mathrm{H}$ NMR $\left(\mathrm{CDCl}_{3}, 25{ }^{\circ} \mathrm{C}, 500 \mathrm{MHz}\right): \delta 0.32$ (s, 6H, SiMe 2 ); 0.77 (s, 9H, CMe 3 ), 6.44 (s, 5H, $\mathrm{C}_{5} H_{5}$ ), $6.55\left(\mathrm{t}, 2 \mathrm{H}, J=2.4 \mathrm{~Hz}, \mathrm{C}_{5} H_{4}\right) ; 6.68(\mathrm{t}, 2 \mathrm{H}, J=2.4 \mathrm{~Hz}$, $\left.\mathrm{C}_{5} H_{4}\right) \cdot{ }^{13} \mathrm{C}\left\{{ }^{1} \mathrm{H}\right\}$ NMR $\left(\mathrm{C}_{6} \mathrm{D}_{6}, 25{ }^{\circ} \mathrm{C}, 300 \mathrm{MHz}\right): \delta$ -5.7 (Si Me $)$; $17.5\left(\mathrm{CMe}_{3}\right) ; 26.5\left(\mathrm{CMe}_{3}\right) ; 115.8\left(C_{5} \mathrm{H}_{5}\right)$; $116.4\left(C_{5} \mathrm{H}_{4}\right) ; 124.1\left(C_{5} \mathrm{H}_{4}\right.$ ipso $) ; 125.3\left(C_{5} \mathrm{H}_{4}\right)$.

\subsection{Synthesis of $\left[\mathrm{Hf}\left(\eta^{5}-\mathrm{C}_{5} \mathrm{H}_{4} \mathrm{SiMe}_{2}^{t} \mathrm{Bu}\right)\left(\eta^{5}-\mathrm{C}_{5} \mathrm{H}_{5}\right) \mathrm{Cl}_{2}\right]$} (6)

Following the same procedure described for $\mathbf{5}$, $\left[\mathrm{Hf}\left(\mathrm{C}_{5} \mathrm{H}_{5}\right) \mathrm{Cl}_{3} \cdot \mathrm{DME}\right](1.58 \mathrm{~g}, 3.6 \mathrm{mmol})$ and $2(0.67 \mathrm{~g}$, $3.6 \mathrm{mmol}$ ) were reacted to give a grey solid which was characterized as $6(1.04 \mathrm{~g}, 2.1 \mathrm{mmol}, 58 \%)$. Anal. Calc. for $\mathrm{C}_{16} \mathrm{H}_{24} \mathrm{SiHfCl}_{2}$ : C, 38.91; H, 4.90. Found: C, 38.65; $\mathrm{H}, 4.81 \% .{ }^{1} \mathrm{H}$ NMR $\left(\mathrm{CDCl}_{3}, 25{ }^{\circ} \mathrm{C}, 300 \mathrm{MHz}\right): \delta 0.32$ (s, 6H, SiMe $)$ ) 0.76 (s, 9H, CMe 3 ); 6.34 (s, 5H, $\mathrm{C}_{5} H_{5}$ ); $6.45\left(\mathrm{t}, 2 \mathrm{H}, J=2.4 \mathrm{~Hz}, \mathrm{C}_{5} H_{4}\right) ; 6.59(\mathrm{t}, 2 \mathrm{H}, J=2.4 \mathrm{~Hz}$, $\left.\mathrm{C}_{5} \mathrm{H}_{4}\right) .{ }^{1} \mathrm{H}$ NMR $\left(\mathrm{C}_{6} \mathrm{D}_{6}, 25{ }^{\circ} \mathrm{C}, 300 \mathrm{MHz}\right): \delta 0.39(\mathrm{~s}$, 6H, SiMe $)$ ); 0.76 (s, 9H, CMe 3 ); $5.87\left(\mathrm{~m}, 7 \mathrm{H}, \mathrm{C}_{5} \mathrm{H}_{4}\right.$ and $\left.\mathrm{C}_{5} H_{5}\right) ; 6.26\left(\mathrm{t}, 2 \mathrm{H}, J=2.4 \mathrm{~Hz}, \mathrm{C}_{5} H_{4}\right) .{ }^{13} \mathrm{C}\left\{{ }^{1} \mathrm{H}\right\} \mathrm{NMR}$ $\left(\mathrm{C}_{6} \mathrm{D}_{6}, 25{ }^{\circ} \mathrm{C}, 300 \mathrm{MHz}\right): \delta-5.6\left(\mathrm{Si}^{\mathrm{M} e_{2}}\right) ; 17.6\left(\mathrm{CMe}_{3}\right)$;
$26.5\left(\mathrm{CMe}_{3}\right) ; 114.4\left(C_{5} \mathrm{H}_{5}\right) ; 115.3\left(C_{5} \mathrm{H}_{4}\right) ; 121.8\left(C_{5} \mathrm{H}_{4}\right.$ ipso $) ; 124.2\left(C_{5} \mathrm{H}_{4}\right)$.

\subsection{Synthesis of $\left[\mathrm{Zr}\left(\eta^{5}-\mathrm{C}_{5} \mathrm{H}_{4} \mathrm{SiMe}_{2}^{t} \mathrm{Bu}_{2}{ }_{2} \mathrm{Cl}_{2}\right]\right.$ (7)}

The same procedure described for $\mathbf{5}$ was followed using 2 (1.08 g, $5.8 \mathrm{mmol})$ and $\left[\mathrm{ZrCl}_{4}(\mathrm{THF})_{2}\right](1.09 \mathrm{~g}, 2.9$ $\mathrm{mmol})$ to give a beige solid characterized as $7(1.17 \mathrm{~g}, 2.4$ mmol, $78 \%$ ). Anal. Calc. for $\mathrm{C}_{22} \mathrm{H}_{38} \mathrm{Si}_{2} \mathrm{ZrCl}_{2}: \mathrm{C}$, 50.73; $\mathrm{H}, 7.35$. Found: $\mathrm{C}, 50.28 ; \mathrm{H}, 7.16 \% .{ }^{1} \mathrm{H}$ NMR $\left(\mathrm{C}_{6} \mathrm{D}_{6}\right.$, $\left.25{ }^{\circ} \mathrm{C}, 200 \mathrm{MHz}\right): \delta 0.44\left(\mathrm{~s}, 12 \mathrm{H}, \mathrm{Si} M e_{2}\right) ; 0.77(\mathrm{~s}, 18 \mathrm{H}$, $\left.\mathrm{CMe}_{3}\right) ; 5.99\left(\mathrm{t}, J=2.5 \mathrm{~Hz}, 4 \mathrm{H}, \mathrm{C}_{5} H_{4}\right) ; 6.41(\mathrm{t}, J=2.4$ $\left.\mathrm{Hz}, 4 \mathrm{H}, \mathrm{C}_{5} H_{4}\right) .{ }^{1} \mathrm{H}$ NMR $\left(\mathrm{CDCl}_{3}, 25{ }^{\circ} \mathrm{C}, 300 \mathrm{MHz}\right): \delta$ 0.32 (s, 6H, SiMe $)$; 0.76 (s, 9H, CMe 3 ); 6.50 (t, $J=2.5$ $\left.\mathrm{Hz}, 4 \mathrm{H}, \mathrm{C}_{5} H_{4}\right) ; 6.64\left(\mathrm{t}, J=2.4 \mathrm{~Hz}, 4 \mathrm{H}, \mathrm{C}_{5} H_{4}\right) .{ }^{13} \mathrm{C}\left\{{ }^{1} \mathrm{H}\right\}$ $\operatorname{NMR}\left(\mathrm{CDCl}_{3}, 25{ }^{\circ} \mathrm{C}, 300 \mathrm{MHz}\right): \delta-5.9\left(\mathrm{Si}^{\mathrm{M} e_{2}}\right) ; 17.4$ $\left(\mathrm{CMe}_{3}\right) ; 26.3\left(\mathrm{CMe}_{3}\right) ; 116.2\left(C_{5} \mathrm{H}_{4}\right) ; 124.1\left(C_{5} \mathrm{H}_{4}\right.$ ipso $)$; $125.8\left(C_{5} \mathrm{H}_{4}\right)$.

\subsection{Synthesis of $\left[\mathrm{Hf}\left(\eta^{5}-\mathrm{C}_{5} \mathrm{H}_{4} \mathrm{SiMe}_{2}^{t} \mathrm{Bu}\right)_{2} \mathrm{Cl}_{2}\right](\boldsymbol{8})$}

The same procedure described for $\mathbf{5}$ was followed using $2(1,42 \mathrm{~g}, 7,6 \mathrm{mmol})$ and $\mathrm{HfCl}_{4}(1.22 \mathrm{~g}, 3.8 \mathrm{mmol})$ to give 8 as a grey solid. (1.30 g, $2.13 \mathrm{mmol}, 56 \%)$. Anal. Calc. for $\mathrm{C}_{22} \mathrm{H}_{38} \mathrm{Si}_{2} \mathrm{HfCl}_{2}$ : C, 43.45; H, 6.30. Found: C, 43.32; H, 6.16\%. ${ }^{1} \mathrm{H}$ NMR $\left(\mathrm{CDCl}_{3}, 25{ }^{\circ} \mathrm{C}, 300 \mathrm{MHz}\right): \delta$ 0.32 (s, 12H, SiMe $) ; 0.76$ (s, 18H, CMe $) ; 6.41$ (m, 4H, $\left.\mathrm{C}_{5} \mathrm{H}_{4}\right) ; 6.55\left(\mathrm{~m}, 4 \mathrm{H}, \mathrm{C}_{5} \mathrm{H}_{4}\right) .{ }^{13} \mathrm{C}\left\{{ }^{1} \mathrm{H}\right\}$ NMR $\left(\mathrm{CDCl}_{3}\right.$, $\left.25{ }^{\circ} \mathrm{C}, 500 \mathrm{MHz}\right): \delta-5.9\left(\mathrm{SiMe}_{2}\right) ; 17.5\left(\mathrm{CMe}_{3}\right) ; 26.3$ $\left(\mathrm{CMe}_{3}\right) ; 115.1\left(C_{5} \mathrm{H}_{4}\right) ; 121.7\left(C_{5} \mathrm{H}_{4}\right.$ ipso $) ; 124.6\left(C_{5} \mathrm{H}_{4}\right)$.

4.9. Synthesis of $\left[M\left(\eta^{5}-C_{5} H_{4} \mathrm{SiMe}_{2}^{c} \mathrm{Bu}\right)\left(\eta^{5}-\right.\right.$ $\left.\left.\mathrm{C}_{5} \mathrm{H}_{5}\right) \mathrm{Me}_{2}\right](\mathrm{Zr}$ 9, $\mathrm{Zr}$ 10)

The dimethyl complexes $\mathbf{9}$ and $\mathbf{1 0}$ were obtained by addition of a $3 \mathrm{M}$ diethylether solution of $\mathrm{MgMeCl}$ to THF solutions of 5 and $\mathbf{6}$, respectively at $-78{ }^{\circ} \mathrm{C}$. The reaction mixture was stirred for $6 \mathrm{~h}$ while it was warmed to r.t. The solvent was removed under vacuum and the residue was extracted into hexane. After the solvent was evaporated under vacuum, the complexes were obtained as waxy oils which were crystallized by cooling their hexane solutions at $-45{ }^{\circ} \mathrm{C}$.

Complex $5(0.85 \mathrm{~g}, 2.1 \mathrm{mmol})$ in THF $(50 \mathrm{ml})$ and $\mathrm{MeMgCl}(1.5 \mathrm{ml}, 4.5 \mathrm{mmol})$ gave 9 as a yellow solid $(0.54 \mathrm{~g}, 1.47 \mathrm{mmol}, 70 \%)$. Anal. Calc. for $\mathrm{C}_{18} \mathrm{H}_{30} \mathrm{SiZr}$ : C, 59.11; H, 8.27. Found: C, 58.88; H, 8.16\%. ${ }^{1} \mathrm{H}$ NMR $\left(\mathrm{C}_{6} \mathrm{D}_{6}, 25{ }^{\circ} \mathrm{C}, 200 \mathrm{MHz}\right): \delta-0.08(\mathrm{~s}, 6 \mathrm{H}, \mathrm{ZrMe}) ; 0.12$ (s, 6H, SiMe $)$; 0.85 (s, 9H, CMe $)$; 5.79 (s, 5H, $\mathrm{C}_{5} H_{5}$ ); $5.95\left(2 \mathrm{~m}, 4 \mathrm{H}, \mathrm{C}_{5} H_{4}\right) .{ }^{1} \mathrm{H}$ NMR $\left(\mathrm{CDCl}_{3}, 25{ }^{\circ} \mathrm{C}, 300\right.$ $\mathrm{MHz}$ ): $\delta-0.40$ (s, 6H, ZrMe $) ; 0.15$ (s, 6H, SiMe $)$; $0.81(\mathrm{~s}, 9 \mathrm{H}, \mathrm{CMe}) ; 6.06\left(\mathrm{~s}, 5 \mathrm{H}, \mathrm{C}_{5} H_{5}\right) ; 6.21(\mathrm{t}, 2 \mathrm{H}, J=$ $\left.2.3 \mathrm{~Hz}, \mathrm{C}_{5} H_{4}\right) ; 6.24\left(\mathrm{t}, 2 \mathrm{H}, J=2.3 \mathrm{~Hz}, \mathrm{C}_{5} H_{4}\right) .{ }^{13} \mathrm{C}\left\{{ }^{1} \mathrm{H}\right\}$ NMR $\left(\mathrm{CDCl}_{3}, 25{ }^{\circ} \mathrm{C}, 300 \mathrm{MHz}\right): \delta-5.8\left(\mathrm{SiMe}_{2}\right) ; 17.5$ $\left(\mathrm{CMe}_{3}\right) ; 26.4\left(\mathrm{CMe}_{3}\right) ; 30.1(\mathrm{ZrMe}) ; 110.4\left(C_{5} \mathrm{H}_{5}\right) ; 114.2$ $\left(C_{5} \mathrm{H}_{4}\right) ; 116.1\left(C_{5} \mathrm{H}_{4}\right.$ ipso $) ; 117.5\left(C_{5} \mathrm{H}_{4}\right)$. 
Complex $6(0.99 \mathrm{~g}, 2.0 \mathrm{mmol})$ in THF $(40 \mathrm{ml})$ and $\mathrm{MeMgCl}(1.35 \mathrm{ml}, 4.0 \mathrm{mmol})$ gave $\mathbf{1 0}$ as a yellow solid (0.68 g, 1.5 mmol, 75\%). Anal. Calc. for $\mathrm{C}_{18} \mathrm{H}_{30} \mathrm{SiHf}$ : C, 47.72 ; H, 6.67 . Found: C, 47.52; H, 6.75\%. ${ }^{1} \mathrm{H}$ NMR $\left(\mathrm{CDCl}_{3}, 25{ }^{\circ} \mathrm{C}, 300 \mathrm{MHz}\right): \delta-0.60\left(\mathrm{~s}, 6 \mathrm{H}, \mathrm{Hf} \mathrm{Me}_{2}\right)$, 0.16 (s, 6H, SiMe $), 0.80$ (s, 9H, CMe $\left.e_{3}\right), 5.99$ (s, 5H, $\left.\mathrm{C}_{5} H_{5}\right), 6.16\left(2 \mathrm{~m}, 4 \mathrm{H}, \mathrm{C}_{5} H_{4}\right) \cdot{ }^{13} \mathrm{C}\left\{{ }^{1} \mathrm{H}\right\}$ NMR $\left(\mathrm{C}_{6} \mathrm{D}_{6}\right.$, $\left.25{ }^{\circ} \mathrm{C}, 300 \mathrm{MHz}\right): \delta-5.7\left(\mathrm{Si}^{\mathrm{M} e_{2}}\right) ; 17.7\left(\mathrm{CMe}_{3}\right) ; 26.6$ $\left(\mathrm{CMe}_{3}\right) 37.1\left(\mathrm{Hf} M e_{2}\right), 110.1\left(C_{5} \mathrm{H}_{5}\right), 110.3\left(C_{5} \mathrm{H}_{4}\right), 113.8$ $\left(C_{5} \mathrm{H}_{4}\right.$ ipso $), 117.5\left(C_{5} \mathrm{H}_{4}\right)$.

4.10. Synthesis of $\left[M\left(\eta^{5}-C_{5} H_{4} S i M e_{2}^{t} B u\right)\left(\eta^{5}-\right.\right.$ $\left.\left.\mathrm{C}_{5} \mathrm{H}_{5}\right)\left(\mathrm{CH}_{2} \mathrm{C}_{6} \mathrm{H}_{5}\right)_{2}\right]$ ( $\left.\mathrm{M}=\mathrm{Ti} \mathrm{11}, \mathrm{Zr} \mathrm{12}, \mathrm{Hf} \mathrm{13}\right)$, $\left[\mathrm{Zr}\left(\eta^{5}-\mathrm{C}_{5} \mathrm{H}_{4} \mathrm{SiMe}_{2}^{t} \mathrm{Bu}\right)_{2}\left(\mathrm{CH}_{2} \mathrm{C}_{6} \mathrm{H}_{5}\right)_{2}\right](\mathrm{14}),\left[\mathrm{Zr}\left(\eta^{5}-\right.\right.$ $\left.\left.\mathrm{C}_{5} \mathrm{H}_{4} \mathrm{SiMe}_{2}^{t} \mathrm{Bu}\right)\left(\eta^{5}-\mathrm{C}_{5} \mathrm{H}_{5}\right)\left(\mathrm{CH}_{2} \mathrm{C}_{6} \mathrm{H}_{5}\right) \mathrm{Cl}\right](\mathrm{15})$ and $\left[\mathrm{Zr}\left(\eta^{5}-\mathrm{C}_{5} \mathrm{H}_{4} \mathrm{SiMe}_{2}^{t} \mathrm{Bu}\right)\left(\eta^{5}-\mathrm{C}_{5} \mathrm{H}_{5}\right)\left(\mathrm{CH}_{2} \mathrm{CMe}_{2} \mathrm{C}_{6} \mathrm{H}_{5}\right)_{2}\right]$ (17)

A $2 \mathrm{M}$ THF solution of $\mathrm{MgBzCl}$ was added at $-78{ }^{\circ} \mathrm{C}$ to $\mathrm{THF}$ solutions of the dichloro complexes 4-7. The mixture was stirred for $1 \mathrm{~h}$ while it was warmed to r.t. The solvent was removed under vacuum and the residue was extracted into hexane. After concentration under vacuum, the complexes were crystallized by cooling their hexane solutions at $-35{ }^{\circ} \mathrm{C}$.

Complex $4(1.30 \mathrm{~g}, 3.6 \mathrm{mmol})$ in THF $(30 \mathrm{ml})$ and $\mathrm{BzMgCl}$ (3.6 ml, $7.2 \mathrm{mmol}$ ) gave complex 11 as a red solid (1.09 g, $2.3 \mathrm{mmol}, 64 \%)$. The product must be protected from light because it is light sensitive. Anal. Calc. for $\mathrm{C}_{30} \mathrm{H}_{38} \mathrm{SiTi}$ : C, 75,92; $\mathrm{H}, 8.07$. Found: $\mathrm{C}$, 76.24; H, 8.22. ${ }^{1} \mathrm{H}$ NMR $\left(\mathrm{CDCl}_{3}, 25{ }^{\circ} \mathrm{C}, 300 \mathrm{MHz}\right): \delta$ 0.06 (s, 6H, SiMe $) ; 0.81$ (s, 9H, CMe $) ; 1.76(\mathrm{~d}, J=$ $\left.10.0 \mathrm{~Hz}, 2 \mathrm{H}, \mathrm{TiCH}_{2}\right) ; 2.03\left(\mathrm{~d}, J=10.0 \mathrm{~Hz}, 2 \mathrm{H}, \mathrm{TiCH}_{2}\right)$; $5.93\left(\mathrm{~s}, 5 \mathrm{H}, \mathrm{C}_{5} H_{5}\right) ; 6.19\left(\mathrm{t}, J=2.4 \mathrm{~Hz}, 2 \mathrm{H}, \mathrm{C}_{5} H_{4}\right) ; 6.30$ $\left(\mathrm{t}, J=2.4 \mathrm{~Hz}, 2 \mathrm{H}, \mathrm{C}_{5} H_{4}\right) ; 7.12-7.19\left(\mathrm{~m}, 10 \mathrm{H}, \mathrm{CH}_{2} P h\right)$.

Complex $5(1.00 \mathrm{~g}, 2.5 \mathrm{mmol})$ in THF $(50 \mathrm{ml})$ and $\mathrm{MgBzCl}(2.5 \mathrm{ml}, 5.0 \mathrm{mmol})$ gave complex 12 as an orange solid $(0.98 \mathrm{~g}, 1.9 \mathrm{mmol}, 76 \%)$. Anal. Calc. for $\mathrm{C}_{30} \mathrm{H}_{38} \mathrm{SiZr}: \mathrm{C}, 69.57 ; \mathrm{H}, 7.40$. Found: C, 70.34; H, $7.46 \% .{ }^{1} \mathrm{H}$ NMR $\left(\mathrm{C}_{6} \mathrm{D}_{6}, 25{ }^{\circ} \mathrm{C}, 200 \mathrm{MHz}\right): \delta 0.03(\mathrm{~s}$, 6H, Si $\left.M e_{2}\right) ; 0.75$ (s, 9H, CMe $)$; 1.89 (2m, 4H, $\mathrm{ZrCH}_{2}$ ); $5.66\left(\mathrm{~s}, 5 \mathrm{H}, \mathrm{C}_{5} H_{5}\right) ; 5.78\left(\mathrm{t}, J=2.4 \mathrm{~Hz}, 2 \mathrm{H}, \mathrm{C}_{5} H_{4}\right) ; 5.88$ $\left(\mathrm{t}, J=2.4 \mathrm{~Hz}, 2 \mathrm{H}, \mathrm{C}_{5} H_{4}\right) ; 6.94\left(\mathrm{~m}, 6 \mathrm{H}, \mathrm{o}-\mathrm{p}-\mathrm{C}_{6} H_{5}\right) ; 7.25$ (m, $\left.4 \mathrm{H}, \mathrm{m}-\mathrm{C}_{6} H_{5}\right) .{ }^{1} \mathrm{H}$ NMR $\left(\mathrm{CDCl}_{3}, 25{ }^{\circ} \mathrm{C}, 500 \mathrm{MHz}\right)$ : $\delta 0.18\left(\mathrm{~s}, 6 \mathrm{H}, \mathrm{Si} M e_{2}\right) ; 0.77\left(\mathrm{~s}, 9 \mathrm{H}, \mathrm{CMe} e_{3}\right) ; 1.83(2 \mathrm{~m}, 4 \mathrm{H}$, $\left.\mathrm{ZrCH}_{2}\right) ; 5.88\left(\mathrm{~s}, 5 \mathrm{H}, \mathrm{C}_{5} H_{5}\right) ; 6.08(\mathrm{t}, J=2.4 \mathrm{~Hz}, 2 \mathrm{H}$, $\left.\mathrm{C}_{5} H_{4}\right) ; 6.16\left(\mathrm{t}, J=2.4 \mathrm{~Hz}, 2 \mathrm{H}, \mathrm{C}_{5} H_{4}\right) ; 6.91(\mathrm{~m}, 6 \mathrm{H}, \mathrm{o}-\mathrm{p}-$ $\left.\mathrm{C}_{6} H_{5}\right) ; 7.18\left(\mathrm{~m}, 4 \mathrm{H}, \mathrm{m}-\mathrm{C}_{6} H_{5}\right) \cdot{ }^{13} \mathrm{C}\left\{{ }^{1} \mathrm{H}\right\}$ NMR $\left(\mathrm{CDCl}_{3}\right.$, $\left.25{ }^{\circ} \mathrm{C}, 500 \mathrm{MHz}\right): \delta-5.7\left(\mathrm{SiMe}_{2}\right) ; 17.5\left(\mathrm{CMe}_{3}\right) ; 26.3$ $\left(\mathrm{CMe}_{3}\right) ; 61.0\left(\mathrm{ZrCH}_{2}\right) ; 112.0\left(C_{5} \mathrm{H}_{4}\right.$ ipso $) ; 112.3\left(C_{5} \mathrm{H}_{5}\right)$; $116.8\left(C_{5} \mathrm{H}_{4}\right) ; 120.1\left(C_{5} \mathrm{H}_{4}\right) ; 120.8\left(\mathrm{p}-C_{6} \mathrm{H}_{5}\right) ; 125.5$ (o$\left.C_{6} \mathrm{H}_{5}\right) ; 128.1\left(\mathrm{~m}-\mathrm{C}_{6} \mathrm{H}_{5}\right) ; 152.4\left(C_{6} \mathrm{H}_{5}\right.$ ipso $) .{ }^{13} \mathrm{C}\left\{{ }^{1} \mathrm{H}\right\}$ NMR $\left(\mathrm{C}_{6} \mathrm{D}_{6}, 25{ }^{\circ} \mathrm{C}, 300 \mathrm{MHz}\right): \delta-5.7\left(\mathrm{SiMe}_{2}\right), 17.6$ $\left(\mathrm{CMe}_{3}\right) ; 26.4\left(\mathrm{CMe}_{3}\right) ; 61.5\left(\mathrm{ZrCH}_{2}\right) ; 112.6\left(C_{5} \mathrm{H}_{5}\right)$; $115.4\left(C_{5} \mathrm{H}_{4}\right.$ ipso $) ; 117.2\left(C_{5} \mathrm{H}_{4}\right) ; 120.3\left(C_{5} \mathrm{H}_{4}\right) ; 121.3$
$\left(\mathrm{p}-C_{6} \mathrm{H}_{5}\right) ; 126.1\left(\mathrm{o}-C_{6} \mathrm{H}_{5}\right) ; 128.5\left(\mathrm{~m}-C_{6} \mathrm{H}_{5}\right) ; 152.8\left(C_{6} \mathrm{H}_{5}\right.$ ipso).

Complex $6(0.93 \mathrm{~g}, 1.9 \mathrm{mmol})$ in THF $(40 \mathrm{ml})$ and $\mathrm{MgBzCl}(1.9 \mathrm{ml}, 3.8 \mathrm{mmol})$ gave $\mathbf{1 3}$ as a yellow solid $(0.79 \mathrm{~g}, 1.3 \mathrm{mmol}, 68 \%)$. Anal. Calc. for $\mathrm{C}_{30} \mathrm{H}_{38} \mathrm{SiHf}: \mathrm{C}$, 59.54; H, 6.33. Found: C, 59.95; H, 6.52\%. ${ }^{1} \mathrm{H}$ NMR $\left(\mathrm{C}_{6} \mathrm{D}_{6}, 25{ }^{\circ} \mathrm{C}, 300 \mathrm{MHz}\right): \delta 0.06\left(\mathrm{~s}, 6 \mathrm{H}, \mathrm{Si} M e_{2}\right) ; 0.74(\mathrm{~s}$, $\left.9 \mathrm{H}, \mathrm{CM} e_{3}\right) ; 1.56\left(\mathrm{~d}, J=11.4 \mathrm{~Hz}, 2 \mathrm{H}, \mathrm{HfCH}_{2}\right) ; 1.66$ (d, $\left.J=11.4 \mathrm{~Hz}, 2 \mathrm{H}, \mathrm{HfCH}_{2}\right) ; 5.62\left(\mathrm{~s}, 5 \mathrm{H}, \mathrm{C}_{5} H_{5}\right) ; 5.76(\mathrm{t}$, $\left.J=2.8 \mathrm{~Hz}, 2 \mathrm{H}, C_{5} \mathrm{H}_{4}\right) ; 5.82\left(\mathrm{t}, J=2.8 \mathrm{~Hz}, 2 \mathrm{H}, C_{5} \mathrm{H}_{4}\right)$; $6.94\left(\mathrm{~m}, 4 \mathrm{H}, \mathrm{o}-\mathrm{C}_{6} H_{5}\right) ; 7.02\left(\mathrm{~m}, 2 \mathrm{H}, \mathrm{p}-\mathrm{C}_{6} H_{5}\right) ; 7.28(\mathrm{~m}$, $\left.4 \mathrm{H}, \mathrm{m}-\mathrm{C}_{6} H_{5}\right) \cdot{ }^{13} \mathrm{C}\left\{{ }^{1} \mathrm{H}\right\}$ NMR $\left(\mathrm{C}_{6} \mathrm{D}_{6}, 25{ }^{\circ} \mathrm{C}, 300 \mathrm{MHz}\right)$ : $\delta \quad-5.7 \quad\left(\mathrm{SiMe}_{2}\right) ; \quad 17.7 \quad\left(\mathrm{CMe}_{3}\right) ; 26.4 \quad\left(\mathrm{CMe}_{3}\right) ; 65.4$ $\left(\mathrm{HfCH}_{2}\right) ; 111.8 \quad\left(C_{5} \mathrm{H}_{5}\right) ; 114.3 \quad\left(C_{5} \mathrm{H}_{4} \quad\right.$ ipso $) ; 116.1$ $\left(C_{5} \mathrm{H}_{4}\right) ; 120.0\left(C_{5} \mathrm{H}_{4}\right) ; 121.7\left(\mathrm{p}-C_{6} \mathrm{H}_{5}\right) ; 126.7\left(\mathrm{o}-C_{6} \mathrm{H}_{5}\right)$; $128.3\left(\mathrm{~m}-\mathrm{C}_{6} \mathrm{H}_{5}\right) ; 152.7\left(C_{6} \mathrm{H}_{5}\right.$ ipso $)$.

Complex $7(1.00 \mathrm{~g}, 1.9 \mathrm{mmol})$ in THF $(30 \mathrm{ml})$ and $\mathrm{MgBzCl}(1.9 \mathrm{ml}, 3.8 \mathrm{mmol})$ gave $\mathbf{1 4}$ as a waxy oil $(0.78 \mathrm{~g}$, $1.23 \mathrm{mmol}, 65 \%$ ). Anal. Calc. for $\mathrm{C}_{36} \mathrm{H}_{52} \mathrm{Si}_{2} \mathrm{Zr}: \mathrm{C}, 68.40$; $\mathrm{H}, 8.29$. Found: $\mathrm{C}, 68.03 ; \mathrm{H}, 8.12 \% .{ }^{1} \mathrm{H}$ NMR $\left(\mathrm{C}_{6} \mathrm{D}_{6}\right.$, $\left.25{ }^{\circ} \mathrm{C}, 300 \mathrm{MHz}\right): \delta 0.09$ (s, $\left.12 \mathrm{H}, \mathrm{Si} M e_{2}\right) ; 0.77$ (s, $18 \mathrm{H}$, $\left.\mathrm{CMe}_{3}\right) ; 1.95\left(\mathrm{~s}, 4 \mathrm{H}, \mathrm{ZrCH}_{2}\right) ; 5.93(\mathrm{t}, J=2.5 \mathrm{~Hz}, 4 \mathrm{H}$, $\left.\mathrm{C}_{5} H_{4}\right) ; 6.05\left(\mathrm{t}, J=2.4 \mathrm{~Hz}, 4 \mathrm{H}, \mathrm{C}_{5} H_{4}\right) ; 6.93-6.99(\mathrm{~m}, 6 \mathrm{H}$, $\left.\mathrm{C}_{6} H_{5}\right) ; 7.23-7.28\left(\mathrm{~m}, 4 \mathrm{H}, \mathrm{C}_{6} H_{5}\right) .{ }^{1} \mathrm{H}$ NMR $\left(\mathrm{CDCl}_{3}\right.$, $\left.25{ }^{\circ} \mathrm{C}, 300 \mathrm{MHz}\right): \delta 0.17$ (s, $\left.12 \mathrm{H}, \operatorname{Si} M e_{2}\right) ; 0.74(\mathrm{~s}, 18 \mathrm{H}$, $\left.\mathrm{CMe}_{3}\right) ; 1.81\left(\mathrm{~s}, 4 \mathrm{H}, \mathrm{ZrCH}_{2}\right) ; 5.94(\mathrm{t}, J=2.5 \mathrm{~Hz}, 4 \mathrm{H}$, $\left.\mathrm{C}_{5} H_{4}\right) ; 6.16\left(\mathrm{t}, J=2.4 \mathrm{~Hz}, 4 \mathrm{H}, \mathrm{C}_{5} H_{4}\right) ; 6.78-6.84(\mathrm{~m}, 6 \mathrm{H}$, $\left.\mathrm{C}_{6} H_{5}\right) ; 7.13-7.18\left(\mathrm{~m}, 4 \mathrm{H}, \mathrm{C}_{6} H_{5}\right) .{ }^{13} \mathrm{C}\left\{{ }^{1} \mathrm{H}\right\} \mathrm{NMR}\left(\mathrm{C}_{6} \mathrm{D}_{6}\right.$, $\left.25{ }^{\circ} \mathrm{C}, 300 \mathrm{MHz}\right): \delta-5.6\left(\mathrm{SiMe}_{2}\right) ; 17.7\left(\mathrm{CMe}_{3}\right) ; 26.4$ $\left(\mathrm{CMe}_{3}\right) ; 63.0\left(\mathrm{ZrCH}_{2}\right) ; 116.6\left(C_{5} \mathrm{H}_{4}\right.$ ipso $) ; 116.9\left(C_{5} \mathrm{H}_{4}\right)$; $120.9\left(C_{5} \mathrm{H}_{4}\right) ; 121.3\left(\mathrm{p}-C_{6} \mathrm{H}_{5}\right) ; 125.9\left(\mathrm{o}-C_{6} \mathrm{H}_{5}\right) ; 128.6(\mathrm{~m}-$ $\left.C_{6} \mathrm{H}_{5}\right) ; 153.6\left(C_{6} \mathrm{H}_{5}\right.$ ipso $)$.

Complex $5(1.60 \mathrm{~g}, 3.9 \mathrm{mmol})$ in THF $(30 \mathrm{ml})$ and $\mathrm{MgBzCl}(1.9 \mathrm{ml}, 3.9 \mathrm{mmol})$ gave $15(1.10 \mathrm{~g}, 2.3 \mathrm{mmol}$, $61 \%$ ) as orange crystals. The product is highly air and light sensitive. Anal. Calc. for $\mathrm{C}_{23} \mathrm{H}_{31} \mathrm{SiZrCl}$ : C, 59.76; $\mathrm{H}, 6.76$. Found: $\mathrm{C}, 59,52, \mathrm{H}, 6.53 \% .{ }^{1} \mathrm{H}$ NMR $\left(\mathrm{C}_{6} \mathrm{D}_{6}\right.$, $25{ }^{\circ} \mathrm{C}, 300 \mathrm{MHz}$ ): $\delta 0.18$ (s, 3H, SiMe $) ; 0.40$ (s, 3H, $\left.\mathrm{Si} M e_{2}\right) ; 0.79$ (s, 9H, CMe $\left.e_{3}\right) ; 2.18(\mathrm{~d}, J=11.7 \mathrm{~Hz}, 1 \mathrm{H}$, $\left.\mathrm{ZrCH}_{2}\right) ; 2.43\left(\mathrm{~d}, J=11.7 \mathrm{~Hz}, 1 \mathrm{H}, \mathrm{ZrCH}_{2}\right) ; 5.39(\mathrm{~m}, 1 \mathrm{H}$, $\left.\mathrm{C}_{5} H_{4}\right) ; 5.68\left(\mathrm{~s}, 5 \mathrm{H}, \mathrm{C}_{5} H_{5}\right) ; 5.73\left(\mathrm{~m}, 1 \mathrm{H}, \mathrm{C}_{5} H_{4}\right) ; 6.03(\mathrm{~m}$, $\left.1 \mathrm{H}, \mathrm{C}_{5} H_{4}\right) ; 6.28\left(\mathrm{~m}, 1 \mathrm{H}, \mathrm{C}_{5} H_{4}\right) ; 6.90-7.10(\mathrm{~m}, 3 \mathrm{H}$, $\left.\mathrm{C}_{6} H_{5}\right) ; 7.28\left(\mathrm{~m}, 2 \mathrm{H}, \mathrm{C}_{6} H_{5}\right)$.

Complex $5(1.34 \mathrm{~g}, 3.3 \mathrm{mmol})$ and $\mathrm{LiCH}_{2} \mathrm{CMe}_{2} \mathrm{Ph}$ $(0.93 \mathrm{~g}, 6.6 \mathrm{mmol})$ in THF $(70 \mathrm{ml})$ gave $17(1.44 \mathrm{~g}, 2.4$ mmol, $73 \%$ ) as a yellow microcrystalline solid. Anal. Calc. for $\mathrm{C}_{36} \mathrm{H}_{50} \mathrm{SiZr}$ : C, 71.81; H, 8.37. Found: C, 71.56; H, 8.39\%. ${ }^{1} \mathrm{H}$ NMR $\left(\mathrm{C}_{6} \mathrm{D}_{6}, 25{ }^{\circ} \mathrm{C}, 500 \mathrm{MHz}\right): \delta$ 0.19 (s, 6H, SiMe $)$ ) 0.78 (s, 9H, CMe 3 ); 0.79 (d, $J=11.5$ $\left.\mathrm{Hz}, 2 \mathrm{H}, \mathrm{ZrCH}_{2}\right) ; 1.03\left(\mathrm{~d}, J=11.5 \mathrm{~Hz}, 2 \mathrm{H}, \mathrm{ZrCH}_{2}\right) ; 1.38$ (s, 6H, CMe 2 ); 1.39 (s, 6H, CMe 2$) ; 5.59$ (s, 5H, $\mathrm{C}_{5} H_{5}$ ); $5.73\left(\mathrm{t}, J=2.5 \mathrm{~Hz}, 2 \mathrm{H}, \mathrm{C}_{5} H_{4}\right) ; 5.82(\mathrm{t}, J=2.5 \mathrm{~Hz}, 2 \mathrm{H}$, $\left.\mathrm{C}_{5} H_{4}\right) ; 7.14\left(\mathrm{~m}, 2 \mathrm{H} \mathrm{p}-\mathrm{C}_{6} H_{5}\right) ; 7.28\left(\mathrm{~m}, 4 \mathrm{H}, \mathrm{o}-\mathrm{C}_{6} H_{5}\right) ; 7.40$ $\left(\mathrm{m}, 4 \mathrm{H}, \mathrm{m}-\mathrm{C}_{6} H_{5}\right) \cdot{ }^{13} \mathrm{C}\left\{{ }^{1} \mathrm{H}\right\}$ NMR $\left(\mathrm{C}_{6} \mathrm{D}_{6}, 25{ }^{\circ} \mathrm{C}, 500\right.$ $\mathrm{MHz}): \delta$-5.3 (SiMe $)$; $17.8\left(\mathrm{CMe}_{3}\right) ; 26.6\left(\mathrm{CMe}_{3}\right) ; 34.7$ $\left(\mathrm{CMe}_{2}\right) ; 36.1\left(\mathrm{CMe}_{2}\right) ; 43.6\left(\mathrm{CMe}_{2}\right) ; 74.1\left(\mathrm{ZrCH}_{2}\right) ; 109.8$ 
$\left(C_{5} \mathrm{H}_{5}\right) ; 113.0\left(C_{5} \mathrm{H}_{4}\right) ; 115.2\left(C_{5} \mathrm{H}_{4}\right.$ ipso $) ; 118.9\left(C_{5} \mathrm{H}_{4}\right)$; $125.5\left(\mathrm{p}-C_{6} \mathrm{H}_{5}\right) ; 126.2\left(\mathrm{o}-C_{6} \mathrm{H}_{5}\right) ; 128.4\left(\mathrm{~m}-C_{6} \mathrm{H}_{5}\right) ; 152.3$ $\left(C_{6} \mathrm{H}_{5}\right.$ ipso $)$.

\subsection{Synthesis of $\left[\left\{\mathrm{Zr}\left(\eta^{5}-\mathrm{C}_{5} \mathrm{H}_{4} \mathrm{SiMe}_{2}^{t} \mathrm{Bu}\right)\left(\eta^{5}-\right.\right.\right.$ $\left.\left.\left.\mathrm{C}_{5} \mathrm{H}_{5}\right) \mathrm{Cl}_{2}\right\}(\mu-\mathrm{O})\right]$ (16)}

Complex $15(0.60 \mathrm{~g}, 1.3 \mathrm{mmol})$ was added to toluene $(20 \mathrm{ml})$ containing water $(12 \mu \mathrm{l}, 0.66 \mathrm{mmol})$ and the mixture was stirred at r.t. for 4 h. After filtration the solvent was removed under vacuum and the residue extracted into hexane. Evaporation of the solvent and cooling at $-35{ }^{\circ} \mathrm{C}$ gave yellow crystals of $16(0.40 \mathrm{~g}, 0.5$ mmol, 81\%). A sample of $\mathbf{1 6}$ for X-ray diffraction was recrystallized from hexane. Anal. Calc. for $\mathrm{C}_{32} \mathrm{H}_{48} \mathrm{Si}_{2} \mathrm{Zr}_{2} \mathrm{Cl}_{2} \mathrm{O}$ : C, 50.69; H, 6.38. Found: C, 50.45, $\mathrm{H}, 6.24 \% .{ }^{1} \mathrm{H}$ NMR $\left(\mathrm{CDCl}_{3}, 25{ }^{\circ} \mathrm{C}, 300 \mathrm{MHz}\right): \delta 0.27$ (s, 3H, SiMe $)$ ); 0.37 (s, 3H, SiMe $) ; 0.74$ (s, 9H, CMe $)$; $6.27\left(\mathrm{~s}, 5 \mathrm{H}, \mathrm{C}_{5} H_{5}\right) ; 6.34\left(\mathrm{~m}, 1 \mathrm{H}, \mathrm{C}_{5} H_{4}\right) ; 6.46(2 \mathrm{~m}, 2 \mathrm{H}$, $\left.\mathrm{C}_{5} \mathrm{H}_{4}\right) ; 6.59\left(\mathrm{~m}, 1 \mathrm{H}, \mathrm{C}_{5} H_{4}\right)$.

\subsection{NMR characterization of $\left[\mathrm{Zr}\left(\eta^{5}-\mathrm{C}_{5} \mathrm{H}_{4} \mathrm{SiMe}_{2}^{t} \mathrm{Bu}\right)\right.$ -} $\left.\left(\eta^{5}-\mathrm{C}_{5} \mathrm{H}_{5}\right)\left(\mathrm{CH}_{2} \mathrm{C}_{6} \mathrm{H}_{5}\right)\right]^{+}\left(\mathbf{1 2}^{+}\right)$

$\mathrm{CD}_{2} \mathrm{Cl}_{2}$ was added at $-78{ }^{\circ} \mathrm{C}$ to a mixture of equimolar amounts of complex 12 and $\mathrm{B}\left(\mathrm{C}_{6} \mathrm{~F}_{5}\right)_{3}$ in a NMR tube. The reaction was monitored by ${ }^{1} \mathrm{H}$ NMR spectroscopy between $193 \mathrm{~K}$ and $273 \mathrm{~K} .{ }^{1} \mathrm{H}$ NMR $\left(\mathrm{CD}_{2} \mathrm{Cl}_{2}, 193 \mathrm{~K}, 500 \mathrm{MHz}\right): \delta 0.12$ (s, 3H, SiMe $\left.)_{2}\right) 0.27$ (s, SiMe $\left.)_{2}\right) 0.78$ (s, 9H, $\mathrm{CMe}_{3}$ ); 2.74 (sb, 2H, $\mathrm{PhCH}_{2} \mathrm{~B}$ ); 3.00 (sb, $\left.2 \mathrm{H}, \mathrm{ZrCH}_{2}\right) ; 6.14$ (s, $\left.5 \mathrm{H}, \mathrm{C}_{5} H_{5}\right) ; 6.38-7.50(\mathrm{~m}$, $\left.14 \mathrm{H}, \mathrm{C}_{5} H_{4}+P h\right){ }^{1} \mathrm{H}$ NMR $\left(\mathrm{CD}_{2} \mathrm{Cl}_{2}, 243 \mathrm{~K}, 500 \mathrm{MHz}\right)$ : $\delta 0.23\left(\mathrm{~s}, 6 \mathrm{H}, \mathrm{Si} M e_{2}\right) ; 0.80\left(9 \mathrm{H}, \mathrm{CM} e_{3}\right) ; 2.78(\mathrm{~b}, 2 \mathrm{H}$, $\mathrm{PhCH}_{2} \mathrm{~B}$ ); 3.07 (bs, $\left.2 \mathrm{H}, \mathrm{ZrCH}_{2}\right) ; 6.16$ (s, 5H, $\mathrm{C}_{5} \mathrm{H}_{5}$ ); 6.71-7.50 (m, 14H, $\left.\mathrm{C}_{5} H_{4}+P h\right)$.

\subsection{3. $X$-ray structure determination of $\left[\mathrm{Ti}\left(\eta^{5}-\right.\right.$ $\left.\left.\mathrm{C}_{5} \mathrm{H}_{4} \mathrm{SiMe}_{2}^{t} \mathrm{Bu}\right)\left(\eta^{5}-\mathrm{C}_{5} \mathrm{H}_{5}\right) \mathrm{Cl}_{2}\right](4)$ and $\left[\left\{\mathrm{Zr}\left(\eta^{5}-\right.\right.\right.$ $\left.\left.\left.\mathrm{C}_{5} \mathrm{H}_{4} \mathrm{SiMe}_{2}^{t} \mathrm{Bu}\right)\left(\eta^{5}-\mathrm{C}_{5} \mathrm{H}_{5}\right) \mathrm{Cl}_{2}\right\}(\mu-\mathrm{O})\right]$ (16)}

Crystals of compound $\mathbf{4}$ and $\mathbf{1 6}$ were obtained by crystallization from toluene and hexane, respectively, and suitable sized crystals, under nitrogen atmosphere, in a Lindemann tube were mounted on a CAD4 diffractometer with graphite-monochromated $\mathrm{Cu} \mathrm{K} \alpha$ radiation $(\lambda=1.541838 \AA)$ The data were collected at $293 \mathrm{~K}$ for 4 and at $173 \mathrm{~K}$ (Oxford Cryosystems, 600 series Cryostream Cooler) for 16. Crystallographic and experimental details are summarized in Table 3. A semiempirical method of absorption correction was applied (maximum and minimum values for the transmission coefficient were 1.000 and 0.748 (4) and 1.000 and 0.807 (16)) [17]. No decay was observed for 4 , while a decay of $15 \%$ was observed during the data collection for $\mathbf{1 6}$. The structures were solved by direct methods (SIR-92) [18] and refined by least-squares against $F_{\mathrm{o}}^{2}$ (SHELXL-97)
Table 3

Crystallographic data of $\mathbf{4}$ and $\mathbf{1 6}$ and details of the structure solutions and refinement procedures

\begin{tabular}{|c|c|c|}
\hline Empirical formula & $\mathrm{C}_{16} \mathrm{H}_{24} \mathrm{Cl}_{2} \mathrm{SiTi}$ & $\mathrm{C}_{32} \mathrm{H}_{48} \mathrm{Cl}_{2} \mathrm{OSi}_{2} \mathrm{Zr}_{2}$ \\
\hline Formula weight & 363.24 & 758.22 \\
\hline Temperature (K) & $293(2)$ & $173(2)$ \\
\hline Wavelength $(\AA ̊)$ & 1.54184 & 1.54184 \\
\hline Crystal system, space group & triclinic, $P-1$ & monoclinic, $C 2 / c$ \\
\hline \multicolumn{3}{|l|}{ Unit cell dimensions } \\
\hline$a(\AA)$ & $6.923(2)$ & $13.401(6)$ \\
\hline$b(\AA)$ & $10.817(3)$ & $7.857(4)$ \\
\hline$c(\AA)$ & $12.940(3)$ & $35.286(9)$ \\
\hline$\alpha\left({ }^{\circ}\right)$ & $70.51(2)$ & \\
\hline$\beta\left({ }^{\circ}\right)$ & $86.02(2)$ & $101.01(2)$ \\
\hline$\gamma\left({ }^{\circ}\right)$ & $83.03(2)$ & \\
\hline$V\left(\AA^{3}\right)$ & $906.3(4)$ & $3647(3)$ \\
\hline$Z$ & 2 & 4 \\
\hline$D_{\text {calc }}\left(\mathrm{Mg} \mathrm{m}^{-3}\right)$ & 1.331 & 1.381 \\
\hline Absorption coefficient $\left(\mathrm{mm}^{-1}\right)$ & 7.239 & 6.826 \\
\hline$F(000)$ & 380 & 1560 \\
\hline Crystal size $\left(\mathrm{mm}^{3}\right)$ & $\begin{array}{l}0.35 \times 0.10 \times \\
0.10\end{array}$ & $0.27 \times 0.17 \times 0.15$ \\
\hline$\theta$ Range for data collection $\left({ }^{\circ}\right)$ & $3.63-69.99$ & $5.11-70.11$ \\
\hline Index ranges & $\begin{array}{l}-7 \leq h \leq 8 \\
-12 \leq k \leq 13 \\
0 \leq l \leq 15\end{array}$ & $\begin{array}{l}-8 \leq h \leq 16 \\
-7 \leq k \leq 9 \\
-42 \leq l \leq 42\end{array}$ \\
\hline $\begin{array}{l}\text { Reflections collected/unique, } \\
R_{\text {int }}\end{array}$ & $3368 / 3368,0.000$ & $6613 / 3446,0.0695$ \\
\hline Data/restraints/parameters & $3368 / 0 / 181$ & $3446 / 0 / 182$ \\
\hline Goodness-of-fit on $F^{2}$ & 0.769 & 1.048 \\
\hline $\begin{array}{l}\text { Final } R \text { indices }[I>2 \sigma(I)] \\
\qquad\left(R_{1}, w R_{2}\right)^{\mathrm{a}}\end{array}$ & $0.0403,0.0601$ & $0.0372,0.0949$ \\
\hline$R$ indices (all data) $\left(R_{1}, w R_{2}\right)^{\mathrm{a}}$ & $0.1208,0.0787$ & $0.0460,0.1028$ \\
\hline $\begin{array}{l}\text { Largest difference peak and } \\
\text { hole }\left(\mathrm{e} \AA^{-3}\right)\end{array}$ & $\begin{array}{l}0.234 \text { and } \\
-0.193\end{array}$ & $\begin{array}{l}1.140 \text { and } \\
-1.069\end{array}$ \\
\hline
\end{tabular}

${ }^{\mathrm{a}} \mathrm{GOOF}=\left[\Sigma\left[w\left(F_{\mathrm{o}}^{2}-F_{\mathrm{c}}^{2}\right)^{2}\right] /(n-p)\right]^{1 / 2}, \quad R_{1}=\Sigma|| F_{\mathrm{o}}|-| F_{\mathrm{c}}|| / \Sigma\left|F_{\mathrm{o}}\right|$, $w R_{2}=\left[\Sigma\left[w\left(F_{\mathrm{o}}^{2}-F_{\mathrm{c}}^{2}\right)^{2}\right] / \Sigma\left[w\left(F_{\mathrm{o}}^{2}\right)^{2}\right]\right]^{1 / 2}, \quad w=1 /\left[\sigma^{2}\left(F_{\mathrm{o}}^{2}\right)+(a P)^{2}+b P\right]$, where $P=\left[\max \left(F_{\mathrm{o}}^{2}, 0\right)+2 F_{\mathrm{c}}^{2}\right] / 3$.

[19]. All the non-hydrogen atoms were refined anisotropically for both compounds. All the hydrogen atoms were introduced from geometrical calculations and refined using a riding model. All the calculations were carried out on the Digital AlphaStation 255 of the 'Centro di Studio per la Strutturistica Diffrattometrica del C.N.R.', Parma. The programs PARst [20] and ORTEP [21] were also used.

\subsection{Ethylene polymerization}

All polymerization experiments were carried out in a $500 \mathrm{ml}$ reactor charged with dry toluene and saturated bubbling ethylene for $30 \mathrm{~m}$ at $1 \mathrm{~atm}$., purified, first over $\mathrm{P}_{2} \mathrm{O}_{5}$ and then through $\mathrm{AlMe}_{3}$. Aliquots of toluene solutions of the cocatalyst MAO (MAO/catalyst $=1000$ / 1) followed by the catalyst $(4.4 \mu \mathrm{mol})$ were injected using a total volume of $100 \mathrm{ml}$ of toluene. The pressure was maintained at $1 \mathrm{~atm}$. and temperature at $21{ }^{\circ} \mathrm{C}$ during the polymerization experiment. After $5 \mathrm{~min}$ the reaction was quenched by addition of $5 \mathrm{ml}$ of a methanol $\mathrm{HCl}$ 
solution (5\%). The suspensions were stirred for $24 \mathrm{~h}$, filtrated and the polymer washed with methanol and dried at $70{ }^{\circ} \mathrm{C}$ for $24 \mathrm{~h}$.

\section{Supplementary material}

Crystallographic data for the structural analysis (excluding structure factors) have been deposited with the Cambridge Crystallographic Data Centre, CCDC Nos. 189194 and 189195 for compounds 4 and 5, respectively. Copies of this information may be obtained free of charge from The Director, CCDC, 12 Union Road, Cambridge, CB2 1EZ, UK (fax: +44-1223-336033; e-mail: deposit@ccdc.cam.ac.uk or www: http:// www.ccdc.cam.ac.uk).

\section{Acknowledgements}

Financial support of our work by MCyT (project MAT2001-1309) is gratefully acknowledged. R.W. and C.R. are grateful to DFG, MEC and Repsol S.A. for fellowships.

\section{References}

[1] (a) A. Togni, R.L. Halterman (Eds.), Metallocenes. Synthesis, Reactivity, Applications, vol. 2, Wiley-VCH, Weinheim, 1998;

(b) H.H. Brintzinger, D. Fischer, R. Mülhaupt, B. Rieger, R.M. Waymouth, Angew. Chem., Int. Ed. Engl. 34 (1995) 1143;

(c) M. Bochmann, J. Chem. Soc., Dalton Trans. (1996) 255;

(d) G.G. Hlatky, Coord. Chem. Rev. 181 (1999) 256; (e) H.G. Alt, A. Köppl, Chem. Rev. 100 (2000) 1205; (f) L. Resconi, L. Cavallo, A. Fait, F. Piemontesi, Chem. Rev. 100 (2000) 1253.

[2] P.C. Möhring, N.J. Coville, J. Organomet. Chem. 479 (1994) 1.

[3] T. Cuenca, P. Royo, Coord. Chem. Rev. 193-195 (1999) 447.

[4] M.V. Galakhov, G. Heinz, P. Royo, Chem. Commun. (1998) 17.

[5] J. Cano, P. Royo, A. Tiripicchio, M.A. Pellinghelli, M. Lanfranchi, Angew. Chem., Int. Ed. Engl. 40 (2001) 2495.

[6] M. Bochmann, M.L.H. Green, A.K. Powell, J. Sassmannshausen, M.U. Triller, S. Wocadlo, J. Chem. Soc., Dalton Trans. (1999) 43.

[7] (a) J.I. Amor, T. Cuenca, M. Galakhov, P. Royo, J. Organomet. Chem. 497 (1995) 127;

(b) J.I. Amor, T. Cuenca, M. Galakhov, P. Gómez-Sal, A. Manzanero, P. Royo, J. Organomet. Chem. 535 (1997) 155.

[8] F. Amor, P. Royo, T.P. Spaniol, J. Okuda, J. Organomet. Chem. 604 (2000) 126.

[9] S.K. Chaudhary, O. Hernandez, Tetrahedron Lett. 20 (1979) 99.

[10] T. Cuenca, P. Gomez-Sal, C. Martin, B. Royo, P. Royo, J. Organomet. Chem. 588 (1999) 134.

[11] M. Koyama, K. Kimura, M. Nakano, H. Yamazaki, Chem. Lett. (1998) 1139.

[12] K.P. Reddy, J.L. Petersen, Organometallics 8 (1989) 2107.

[13] G. Ciruelo, T. Cuenca, P. Gomez-Sal, A. Martin, P. Royo, J. Chem. Soc., Dalton Trans. (1995) 231.

[14] E.C. Lund, T. Livinghouse, Organometallics 9 (1990) 2426.

[15] L.E. Manzer, Inorg. Synth. 21 (1982) 135.

[16] A.G. Massey, A.J. Park, J. Organomet. Chem. 2 (1964) 245

[17] A.C.T. North, D.C. Phillips, F.S. Mathews, Acta Crystallogr., A 24 (1968) 351.

[18] A. Altomare, G. Cascarano, C. Giacovazzo, A. Guagliardi, M.C. Burla, G. Polidori, M. Camalli, J. Appl. Crystallogr. 27 (1994) 435.

[19] G.M. Sheldrick, SHELXL-97, Program for the Refinement of Crystal Structures, Universität Göttingen, Göttingen, Germany, 1997.

[20] M. Nardelli, Comput. Chem. 7 (1983) 95.

[21] L. Zsolnai, H. Pritzkow, zortep. ORTEP, Original Program Modified for the PC, Universität Heidelberg, Heidelberg, Germany, 1994. 